\title{
Evolução correlacionada de caracteres de frutos e defesas em palmeiras neotropicais
}

\author{
Associated evolution of fruit and defensive traits in \\ Neotropical palms
}

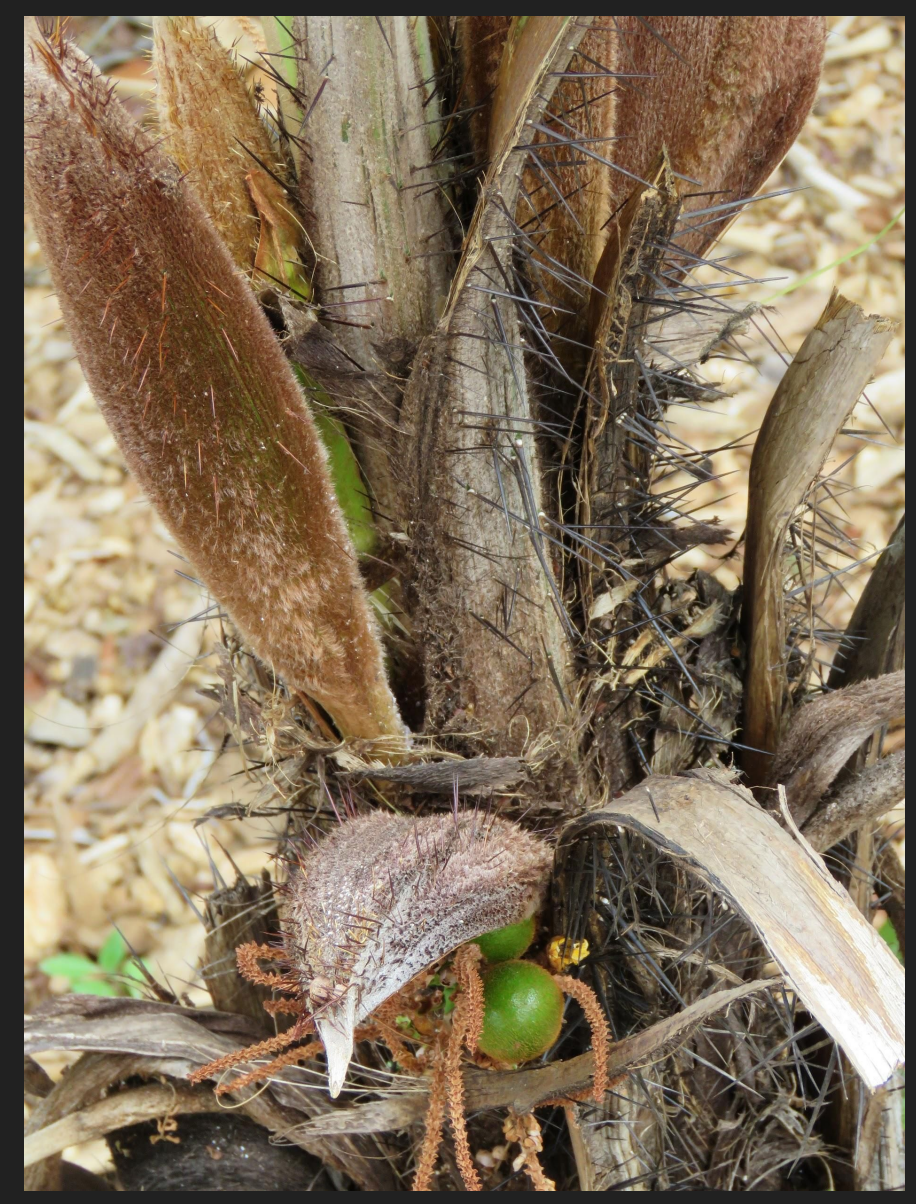

São Paulo 


\author{
Universidade de São Paulo \\ Instituto de Biociências \\ Programa de Pós-Graduação em Ecologia
}

\title{
Evolução correlacionada de caracteres de frutos e defesas em palmeiras neotropicais
}

\section{Associated evolution of fruit and defensive traits in Neotropical palms}

Lucas Ferreira do Nascimento

\begin{abstract}
Dissertação apresentada ao Instituto de Biociências da Universidade de São Paulo, para a obtenção de Título de Mestre em Ecologia, na área de Ecologia: Ecossistemas Terrestres e Aquáticos.
\end{abstract}

Orientador: Prof. Dr. Mathias Mistretta Pires

São Paulo

2019 
Ficha catalográfica elaborada pelo Serviço de Biblioteca do Instituto de Biociências da USP, com os dados fornecidos pelo autor no formulário:

http://www.ib.usp.br/biblioteca/ficha-catalografica/ficha.php

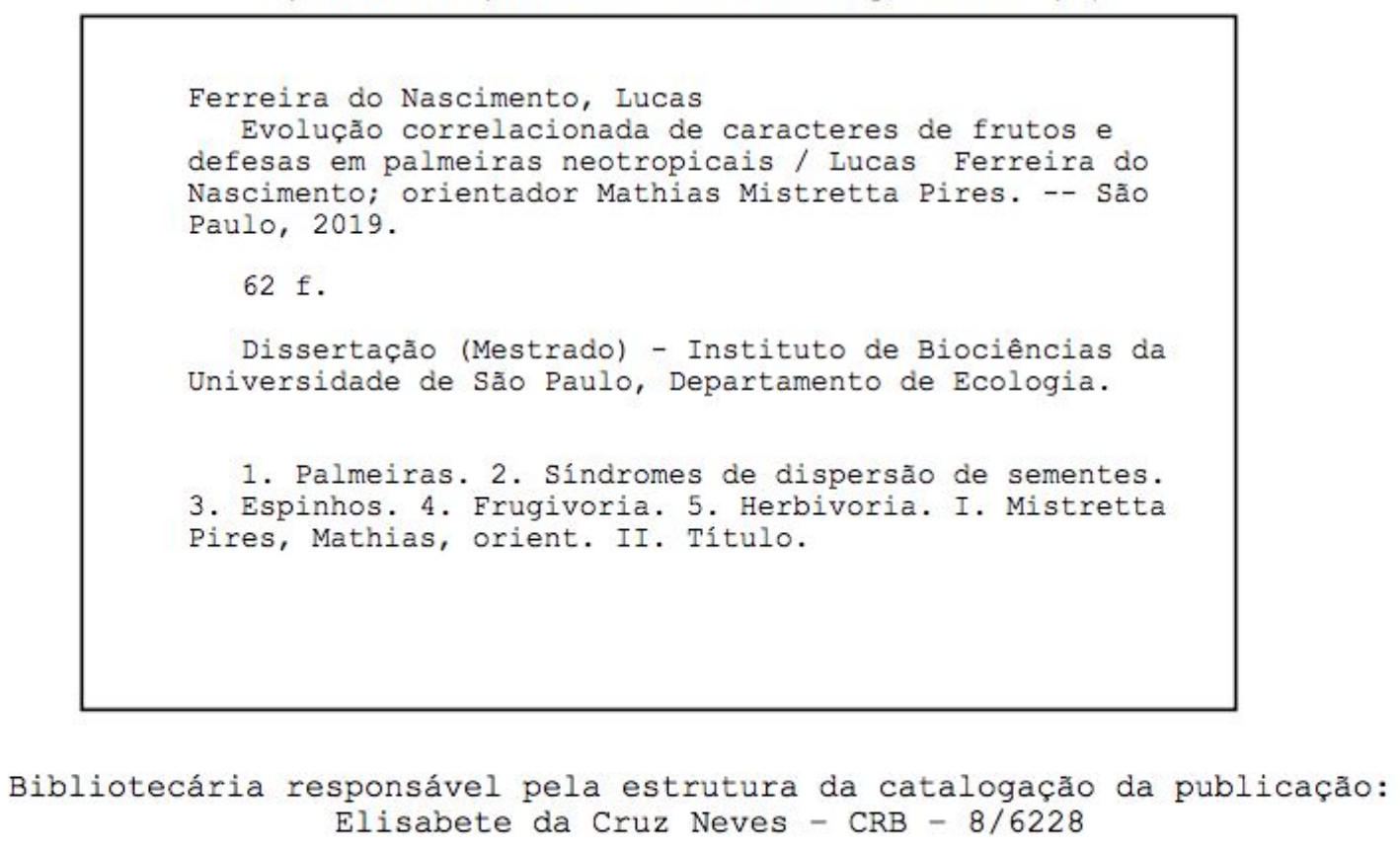

Capa: Macaubinha (Acrocomia glaucescens), em Instituto Plantarum Nova Odessa - SP.

Foto: Lucas F. Nascimento 


\section{Comissão julgadora:}

$\operatorname{Prof(a).} \operatorname{Dr}(\mathbf{a})$.

$\operatorname{Prof(a).~Dr(a).~}$

Prof(a). Dr(a).

Orientador: Prof. Dr. Mathias Mistretta Pires 
A toda comunidade cujo o direito de sonhar foi roubado 
Na boca da mata eu avistei

Um pássaro cantando

Avisando que cheguei

Guardiões dos caminhos

Me protejam dos espinhos

Que trago no coração

Ciência boa...

Guitinho da Xambá (Bongar) 


\section{Agradecimentos}

Em poucas palavras, mas com todo o meu coração eu agradeço:

À CNPQ pelo financiamento.

A todos (as) professores (as) e funcionários (as) da USP, IB e Departamento de Ecologia IB - USP.

Á Vera Lima e Shirlene Barros, pela solicitude em me ajudar com um dos meus maiores desafios da vida acadêmica: burocracias.

À Profa. Dra. Renata Pardini, Prof. Dr. Alexandre Adalardo, Prof. Dr. Paulo Inácio, Prof. Dr. Glauco Machado e Prof. Dr. Eduardo Santos, pelas conversas e disciplinas sensacionais.

Ao Prof. Dr. Mauro Galetti e Prof. Dr. Marco Pizo, pelas belíssimas ideias e apoio no meu comitê de acompanhamento.

A todo o pessoal do LABIC, por me receber e me ensinar muito da história natural de frugivoria.

Ao Dr. Gustavo Burin e Dra. Laura Alencar, pela grande ajuda com as análises.

À LAGE (Em especial: Soly, Danilo Axpira, Érika, João Menezes, Dieguito Sanches "el matador", Bruno, Bruna, Alexandre VP, Torrone, Greg, Louisse, Billy Requena) pela amizade, risadas, cafés, ajuda com o R e pelo ambiente estimulante de trabalho.

A todos (as) do Curso de Campo da Mata Atlântica 2017, em especial a galera do Xorume, por me ensinar tanto, em tão pouco tempo, com tanta risada! 
Ao Guimarães LAB (Paulinha Assis, Andrés, Dani, Pamm, Pâmela, Lucas Camacho, Coral, Anna, Alice, Marina, Leandro, Paulinha Lemos, Irina, Bruno Melati, Lucas Pinguim, Bia, Pato, Má Gaiarsa, Rafael Raimundo, Roberta, Titilia, Juli, Flavia, Mari, Kate), pelas cervejas, risadas, retiros, reuniões, discussões de artigos, fascínio por interações ecológicas e torcida!

Ao Prof. Dr Paulo R. Guimarães Jr. (Miúdo), pela amizade, confiança, por me abrir várias portas, por me aceitar como agregado no laboratório e por me ajudar em diversas dimensões da minha vida.

Ao Prof. Dr. Mathias Mistretta Pires, pela orientação, paciência e busca pela excelência sem perder de vista o meu aprendizado.

Aos meus irmãos do Dona Crô (Rommel, Juninho, Jhow, Chico, Iuri), pela parceria e por me fazer se sentir um músico.

Aos meus irmãos do Babilônia 309 (Daniel, Marco, André), pela força e parceria.

Aos meus irmãos do Quilombo 208 (Marquinhos, Titi, Paulão, Rafinha), pela amizade e irmandade.

À Capoeira, ao meu Mestre Pinguim e todos(as) do Guerreiros de Senzala, por me ensinar a vencer o banzo.

A minha família (Mãe Marilene, Lili, Kátia, Rogério Jackson, Stevan), por tudo. Em especial minha sobrinhada (Thata, Roger, Gabriel, Pietro, Alice, Vitão, Laurinha), por todo carinho e magia.

Ao meu sogro Nego Val e minha sogra Vaninha, por me acolherem como um filho e me abraçarem como uma família! 
A tudo (inclusive o que eu não vejo) e todos (as) que de alguma forma me fortaleceram nesta caminhada.

À minha amada Maytê Amarante, por ser a minha companheira maravilhosa! Por me escolher! Por me inspirar! Por me amar!

Obrigado! 


\section{Table of contents}

$\begin{array}{ll}\text { Prefácio } & 10\end{array}$

$\begin{array}{ll}\text { Single chapter } & 24\end{array}$

$\begin{array}{ll}\text { Abstract } & 25\end{array}$

$\begin{array}{ll}\text { Resumo } & 26\end{array}$

\begin{tabular}{ll} 
Introduction & 27 \\
\hline
\end{tabular}

$\begin{array}{ll}\text { Material and Methods } & 30\end{array}$

Data on fruit size, fruit color and spines $\quad 30$

$\begin{array}{ll}\text { Phylogenies and phylogenetic uncertainty } & 31\end{array}$

Ancestral state reconstructions and evolutionary trait regimes $\quad 31$

Evolutionary relationship between fruit length, fruit colors and spines $\quad 32$

$\begin{array}{ll}\text { Results } & 35\end{array}$

Ancestral state reconstruction and evolutionary trait regimes $\quad \mathbf{3 5}$

Evolutionary relationship between fruit length, fruit colors and spines $\quad \mathbf{3 6}$

$\begin{array}{lr}\text { Discussion } & 39\end{array}$

$\begin{array}{ll}\text { Acknowledgements } & 44\end{array}$

$\begin{array}{ll}\text { Funding } & 44\end{array}$

$\begin{array}{ll}\text { References } & 44\end{array}$

Supplementary material $\quad 56$ 


\section{Prefácio}

Uma das maiores paixões de naturalistas e amantes da natureza são as interações ecológicas entre plantas e animais. Essas interações chamam a nossa atenção não apenas pela beleza e diversidade mas também pelas suas implicações ecológicas e evolutivas nas populações. Mutualismos e antagonismos, como dispersão de sementes e herbivoria, influenciam a aptidão dos indivíduos de plantas de forma positiva e negativa respectivamente. Os efeitos na aptidão dos indivíduos resultam em efeitos demográficos no nível populacional determinando também os padrões de evolução de caracteres nas espécies. Contudo, entender como interações de dispersão de sementes e herbivoria podem moldar a dinâmica evolutiva dos caracteres de plantas permanece um desafio em biologia evolutiva. O meu grande interesse pelos efeitos evolutivos das interações foi o principal combustível para eu começar este trabalho de mestrado. Aqui eu vou introduzir brevemente o arcabouço teórico de dispersão de sementes e herbivoria e as primeiras ideias que levaram ao desenvolvimento dessa dissertação.

Diversos fatores influenciam a germinação de sementes e o recrutamento das plântulas. O sucesso do recrutamento depende das condições locais onde as sementes são depositadas e de como essas condições influenciam o sucesso de estabelecimento e desenvolvimento do indivíduo (Wenny 2001). O local onde a planta mãe ocorre, por definição, deve possuir as condições e recursos necessários para o desenvolvimento de indivíduos daquela espécie. No entanto, próximo à planta mãe, as plântulas podem ser prejudicadas pela competição intraespecífica tanto com as outras plântulas quanto com a planta mãe (Connel 1971, Janzen 1970). Além disso, o acúmulo de sementes pode beneficiar patógenos e predadores de sementes, aumentando a taxa de mortalidade e reduzindo o sucesso per capita (Connel 1971, Janzen 1970). Desta forma, espera-se que as chances de recrutamento das plântulas sejam maiores em locais mais distantes da planta-mãe (Connel 1971, Janzen 1970). Se dispersores auxiliam no transporte de sementes a sítios adequados ao recrutamento, o efeito dos fatores responsáveis pela mortalidade é 
reduzido, aumentando a probabilidade de sucesso de estabelecimento dos embriões e seu desenvolvimento em novos indivíduos (Shupp 2010). Assim, dispersores de sementes têm um papel fundamental na sobrevivência dos embriões e recrutamento das plântulas (Wenny 2001). A dispersão de sementes é também responsável, junto à polinização, pelo fluxo gênico, introduzindo variabilidade nas populações locais e pela colonização de novos sítios, ampliando a distribuição de espécies vegetais e promovendo a sua persistência ao longo do tempo (Vander Wall et al. 2011).

A estimativa de que aproximadamente $90 \%$ das angiospermas tropicais dependem de animais para dispersão de sementes (Jordano 2000) ilustra o quanto essas interações são importantes para as espécies vegetais e para os ecossistemas de maneira geral. Muitas plantas dependem de aves, mamíferos, répteis, peixes e até mesmo formigas para dispersar suas sementes. Contudo, aves e mamíferos são os principais dispersores de sementes na maioria dos ambientes terrestres. Aves e mamíferos diferem em capacidade visual e comportamento de manipulação dos frutos (Fleming \& Kress 2013). As aves têm maior capacidade visual que mamíferos e geralmente ingerem frutos inteiros, por outro lado, os mamíferos possuem um tamanho corpóreo maior, manipulam os frutos e, assim, conseguem ingerir frutos maiores (Fuzessy et al. 2018). Como consequência, as características dos frutos podem ser associadas a características morfológicas, fisiológicas e comportamentais dos frugívoros (Gautier-Hion et al. 1985; Janson 1983, Cazetta et al. 2009). O conjunto de características de frutos associados a determinados frugívoros são chamados de síndromes de dispersão. Frutos consumidos por aves tendem a ser pequenos e com cores chamativas (preto, vermelho, violeta) que contrastam com a folhagem. Por outro lado, frutos consumidos por mamíferos tendem a ser maiores que os frutos de aves e com cores menos chamativas (marrom, verde, amarelo, laranja) e não contrastantes. O quanto essa associação entre caracteres de frutos e frugívoros pode estar associada a uma simples preferência dos frugívoros a determinados frutos ou a uma resposta a pressões seletivas de diferentes frugívoros a diferentes características dos frutos é uma questão que tem sido amplamente discutida na literatura (Lomáscolo et al. 2010).

Ao passo que a maioria das angiospermas têm seus frutos consumidos por frugívoros, virtualmente todas as plantas são consumidas por pelo menos um herbívoro. A herbivoria pode diminuir a aptidão das plantas reduzindo o crescimento, sobrevivência e/ou reprodução (Strauss \& Agrawal 1999). Consequentemente, ao longo da história evolutiva 
das plantas, diferentes estratégias de defesas químicas (e.g. toxinas), tolerância (e.g. rebrotamento) e defesas mecânicas (e.g. espinhos) contra herbívoros foram favorecidas pela evolução. Estruturas duras e pontiagudas como espinhos podem ter origem em modificações de diferentes órgãos. Por exemplo, em palmeiras do gênero Phoenix os espinhos se originam de folhas jovens modificadas (Simpson 2010), por outro lado em palmeiras do gênero Cryosophila os espinhos se originam de raízes modificadas no caule (Jackson 1986). Na literatura, a nomenclatura pode variar e definir "espinhos" como órgãos modificados em estruturas pontiagudas vascularizadas e "acúleos" como projeções do córtex ou epiderme, não vascularizados (e.g. estruturas presentes em rosas; Bell 1997). Nessa dissertação, baseado em trabalhos anteriores, eu chamo de "espinho" qualquer estrutura dura e pontiaguda, vascularizada ou não (Charles-Dominique et al. 2016, Grubb 1992, Evert et al. 2013). Enquanto as defesas químicas estão principalmente associadas à defesa contra insetos, estruturas como espinhos, promovem defesas mecânicas contra vertebrados (Grubb 1992). Por exemplo, folhas com espinhos tendem a sofrer menos herbivoria por ungulados do que folhas sem espinhos (Cooper \& Owen-Smith 1986) e as plantas podem produzir espinhos maiores e em maior quantidade em áreas com ungulados do que áreas sem ungulados (Goheen et al. 2007). Resultados recentes sugerem ainda que, na África, a história evolutiva de plantas com espinhos foi congruente com a história evolutiva de bovídeos (Charles-Dominique 2016).

Podemos investigar o papel dos frugívoros e herbívoros na evolução de caracteres de plantas estudando características dos frutos e espinhos respectivamente. Muitos trabalhos têm mostrado uma evolução correlacionada entre tamanho de fruto e cores relacionadas a aves e mamíferos sugerindo uma assinatura evolutiva de síndromes de dispersão por aves e mamíferos (Lomáscolo et al. 2010; Nevo et al. 2018; Valenta et al. 2018). Nesse sentido as interações com frugívoros seriam responsáveis por moldar a dinâmica evolutiva desse diferentes atributos dos frutos como coloração e tamanho, gerando as combinações observadas no presente. Outros estudos contudo, sugerem que atributos como tamanho do fruto respondem às pressões seletivas impostas por frugívoros, mas a coloração seria menos responsiva, dependendo de condições locais ou de variações no metabolismo (Brodie 2017). Portanto, a generalidade da assinatura evolutiva de síndromes de dispersão em diferentes táxons e regiões não é bem compreendida (Lomáscolo et al. 2010). As relações entre os atributos relacionados a diferentes tipos de interação são ainda menos compreendidas. 
Durante o desenvolvimento da planta, o investimento em defesas contra herbívoros, pode influenciar o investimento em estruturas reprodutivas comprometendo o sucesso reprodutivo. Por exemplo, em Acacia drepanolobium, o tamanho do espinho é negativamente relacionada com a biomassa de sementes produzidas (Goheen et al. 2007). Em escala evolutiva, essas relações poderiam produzir associações negativas entre atributos relacionados à defesa e atributos relacionados à dispersão como tamanho dos frutos. Por outro lado, grandes frugívoros são capazes de dispersar sementes grandes mas também podem consumir outras partes das plantas (e.g. elefantes, Chapman et al. 1992, Sekar \& Sukumar 2015). Assim, ao mesmo tempo que esses grandes frugívoros podem exercer pressão favorecendo o aumento do tamanho de fruto eles poderiam exercer pressão seletiva sobre defesas contra herbivoria. Se essa pressão seletiva for consistente em grandes escalas de tempo, poderíamos esperar uma evolução correlacionada entre frutos grandes e a presença de espinhos.

Dentre os muitos grupos de plantas que habitam os trópicos, as palmeiras (família Arecaceae) se destacam pela sua importância ecológica, estando usualmente entre as plantas dominantes em densidade e estabelecendo interações com diferentes organismos (Staggemeier et al. 2016, Steege et al. 2013). Nos neotrópicos, a família Arecaceae conta com aproximadamente 550 espécies que possuem frutos (em geral, drupas com $1-4$ sementes) de diferentes tamanhos, colorações e uma variedade de defesas mecânicas contra herbivoria. (figura 1; Henderson et al. 1997). Os frutos de palmeiras neotropicais são consumidos por uma variedade de frugívoros (Zona \& Henderson 1989), incluindo grandes mamíferos (e.g. anta, queixada), aves (e.g. sabiás, tucanos, jacús), roedores estocadores (e.g. esquilos e cutias) e até mesmo répteis (e.g. teiús) e peixes (e.g. pacu; Galetti et al. 2008). Além de frutos e sementes, outras partes das palmeiras podem ser atrativas para a fauna. Queixadas (Tayassu pecari), por exemplo, podem ser importantes dispersores de sementes de palmeiras, mas também podem predar as sementes, consumir folhas, flores e raízes, além de pisotear plântulas (Beck 2006). Como consequência, frugívoros e herbívoros podem influenciar de forma positiva ou negativa o recrutamento das plântulas de palmeiras. Toda essa variedade de espécies e interações com frugívoros e herbívoros fazem das palmeiras um sistema de estudo ideal para investigarmos as consequências ecológicas e evolutivas das interações entre plantas e vertebrados. 
Para compreender melhor como interações ecológicas influenciam as características das plantas que observamos no presente, eu investiguei a história evolutiva de caracteres relacionados à dispersão de sementes (tamanho e coloração de fruto) e herbivoria (espinhos) usando palmeiras neotropicais como sistema de estudo. Utilizando informações disponíveis na literatura, eu construí um banco de dados com informações para coloração de frutos de 434 espécies e informações de tamanho de fruto e espinhos para 530 espécies de palmeiras neotropicais. A seguir eu descrevo alguns aspectos gerais desse conjunto de dados e apresento análises preliminares que motivaram a análise mais aprofundada sobre a dinâmica evolutiva de caracteres que apresento no capítulo seguinte.

\section{Frutos e Espinhos em Palmeiras Neotropicais}

O tamanho médio dos frutos de palmeiras neotropicais varia entre 0,4 e $12,5 \mathrm{~cm}$ (excluindo Cocos nucifera, que possui frutos consideravelmente maiores, mas tem origem extratropical), sendo que a maioria das espécies (63\%) de palmeiras neotropicais possuem frutos menores do que $2 \mathrm{~cm}$ (figura 2). Dentre as 530 espécies analisadas, 257 (59\%) possuem cores de frutos relacionadas à dispersão por aves (preto, vermelho, violeta) e 177 (41\%) possuem cores de fruto relacionadas a mamíferos (marrom, verde, amarelo, laranja). Quanto à presença de espinhos, 164 espécies (31\%) de palmeiras possuem espinhos nas folhas, raque, estipe ou bráctea peduncular. Quando olhamos para a relação entre tamanho de fruto e cores relacionadas a dispersão por aves e mamíferos, nota-se que os frutos com cores relacionadas a aves são, em geral, menores do que os frutos relacionados a mamíferos como sugerido pelas síndromes de dispersão (figuras 3 - 4a). Por outro lado, percebe-se que, atualmente, não há diferença entre o tamanho médio de frutos de palmeiras com espinhos e sem espinhos (figuras 4b). 


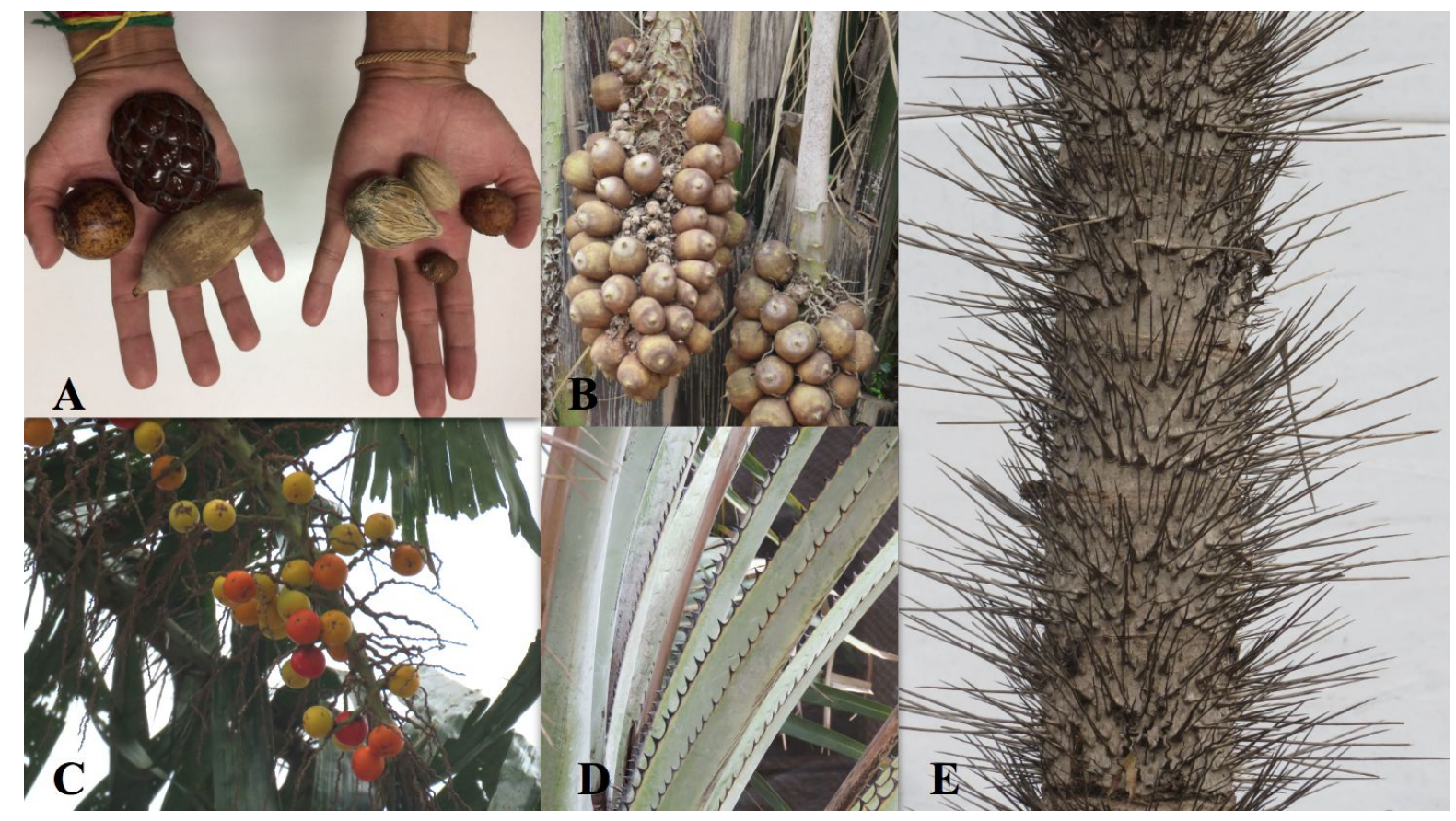

Figura 1. (A) Frutos de palmeiras exemplificando a variação no tamanho. (B) Frutos de Attalea brasiliensis. (C) Frutos de Aiphanes aculeata (D) Espinhos distribuídos na base das folhas de Copernicia baileyana (E) Espinhos distribuídos no estipe de Aiphanes aculeata. Fotos: Lucas F. Nascimento, em Instituto Plantarum Nova Odessa - SP.

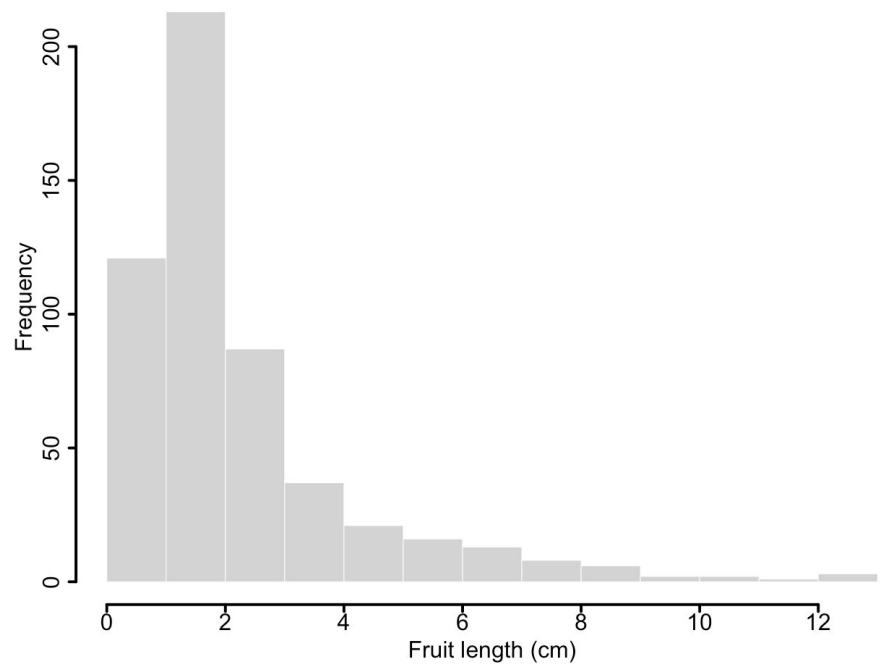

Figure 2. Distribuição do comprimento médio do fruto $(\mathrm{cm})$ considerando todas as espécies de palmeiras neotropicais nas análises ( $\mathrm{n}=530$ espécies de palmeiras neotropicais) 


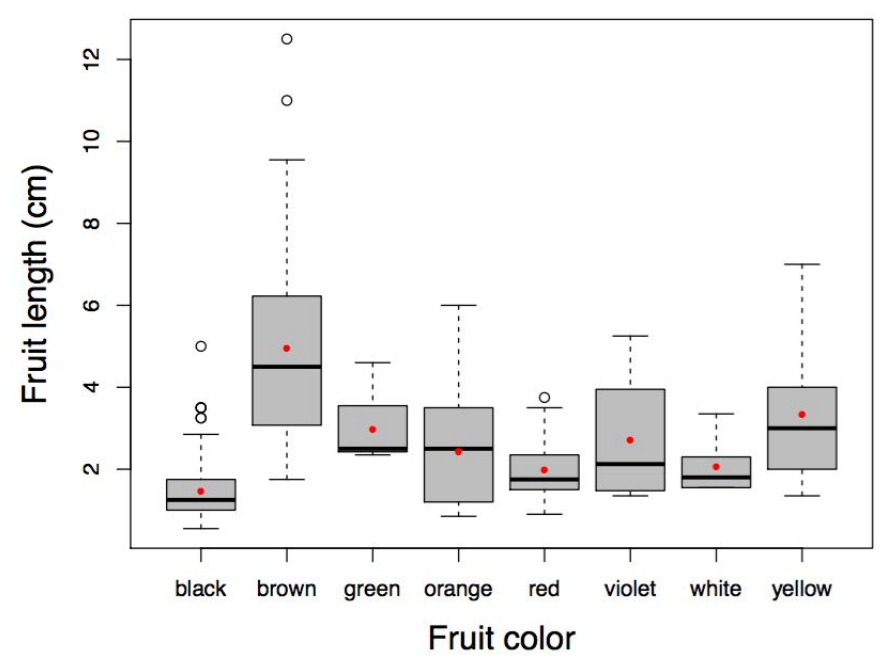

Figure 3. Comprimento do fruto $(\mathrm{cm})$ em função da coloração dos frutos. Pontos vermelhos indicam as médias. A linha preta horizontal indica as medianas. As barras verticais se estendem ao ponto que corresponde a 1.5 vezes a distância interquartil a partir dos limites das caixa.

A

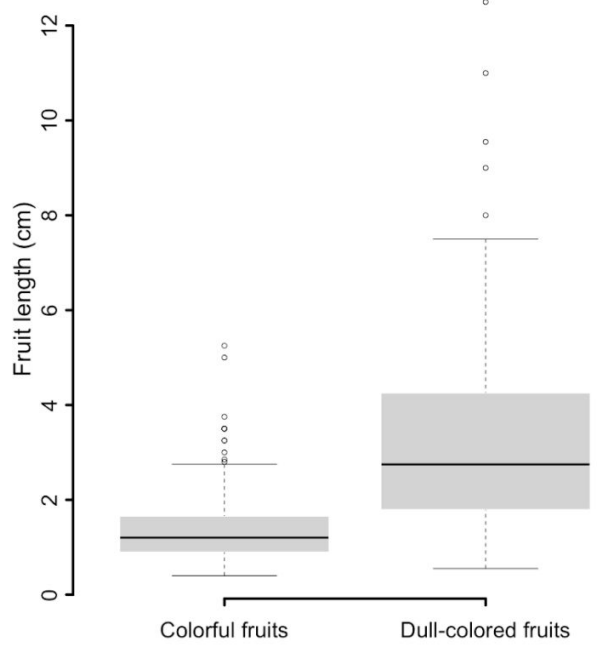

B

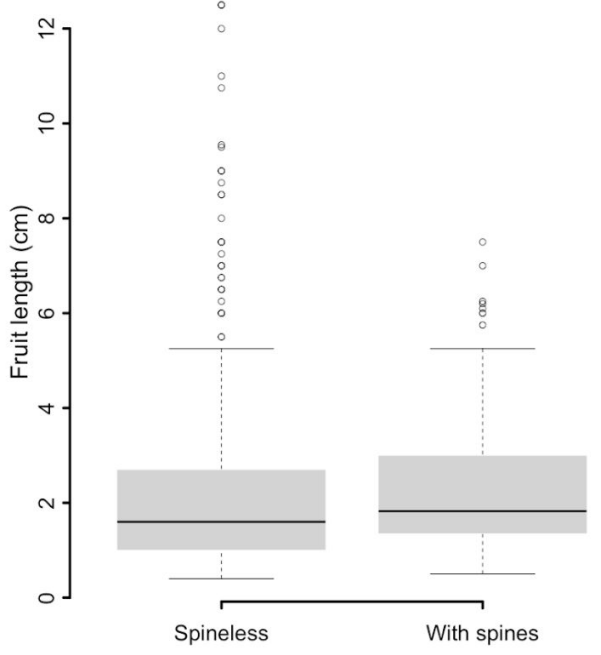

Figure 4. (A) Comprimento dos frutos $(\mathrm{cm})$ em função da coloração dos frutos relacionadas a aves (colorful fruits) e mamíferos (Dull-colored fruits). (B) Comprimento dos frutos em função da presença (with spines) e ausência de espinhos (spineless). (A - B) A linha preta horizontal indica as medianas. As barras verticais se estendem ao ponto que corresponde a 1.5 vezes a distância interquartil a partir dos limites das caixa. 
Esses resultados nos permitem entender melhor a distribuição e relação entre caracteres de frutos e espinhos no presente. Todavia, sabemos que o passado influencia o presente, de tal maneira que a história evolutiva compartilhada das espécies determina em parte a relação atual entre os estados de caracteres das espécies (Felsenstein 1985). Portanto, para entender a distribuição atual dos caracteres nos clados é necessário examinar também a história evolutiva desses caracteres. Os Métodos Filogenéticos Comparativos consistem de modelos matemáticos e técnicas estatísticas que utilizam as relações filogenéticas entre táxons para responder questões sobre a evolução dos caracteres e diversificação das linhagens evolutivas. Métodos Filogenéticos Comparativos foram utilizados por exemplo para elucidar a relação entre taxas de diversificação e a dieta de aves (Burin et al. 2016), sugerindo que a dieta onívora está associada a altas taxas de extinção e baixas taxas de especiação. Em outro estudo investigando a relação evolutiva entre defesas mecânicas e químicas de plantas contra herbivoria (Nevo et al. 2017), os autores sugerem uma evolução independente entre defesas mecânicas e químicas. Finalmente. em estudos recentes investigando o efeito do tamanho de fruto de palmeiras (Onstein et al. 2017) nas taxas de especiação e extinção, encontrou-se que frutos pequenos $(<4 \mathrm{~cm})$ estão associados a uma alta taxa de especiação comparados com frutos grandes $(\geq 4 \mathrm{~cm})$.

Considerando a importância da história evolutiva compartilhada em determinar padrões de similaridade em atributos morfo-funcionais, utilizei abordagens de métodos filogenéticos comparativos, para investigar mais a fundo as distribuições desses atributos e examinar a evolução de tamanho de fruto, coloração de fruto e espinhos de palmeiras neotropicais. Utilizando as filogenias mais atuais no nível de espécies gerada para Arecaceae (Faurby et al. 2016), eu analisei como estão distribuídos o tamanho de fruto, coloração e presença/ausência de espinhos ao longo da filogenia. Podemos ver que a maioria das espécies de palmeiras possuem frutos pequenos (figura 5), com coloração relacionada a aves (figura 6 - 7) e sem espinhos (figura 8). Linhagens com frutos grandes (figura 5), coloração relacionada à dispersão por mamíferos (figura 6 - 7) e com espinhos (figura 8) estão concentrados em alguns clados. 


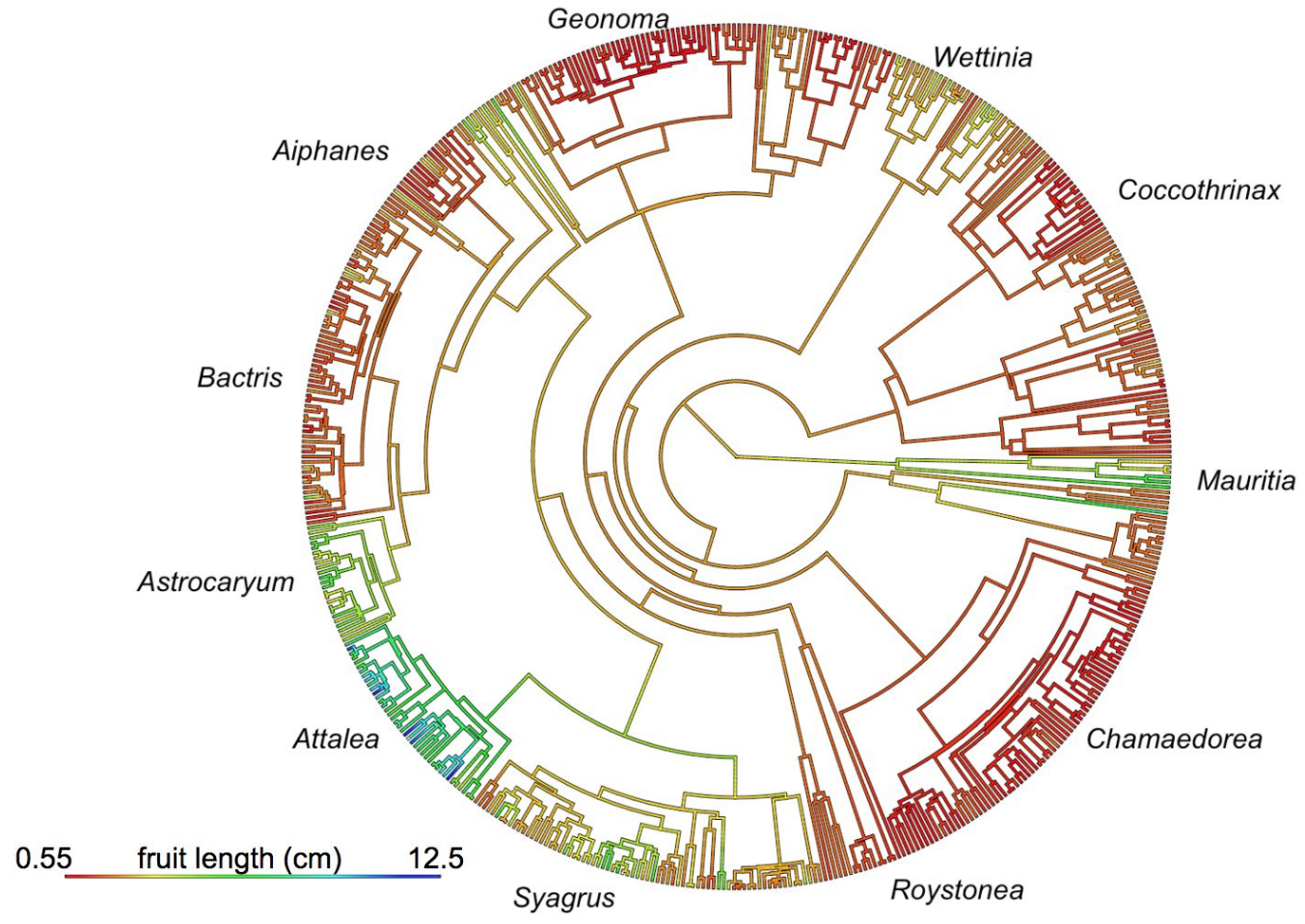

Figure 5. Reconstrução dos estados ancestrais do comprimento de fruto $(\mathrm{cm})$ para espécies de palmeiras neotropicais. Cores mais quentes indicam menor tamanho de fruto na respectiva linhagem. Alguns gêneros estão indicados nas pontas, como exemplo.

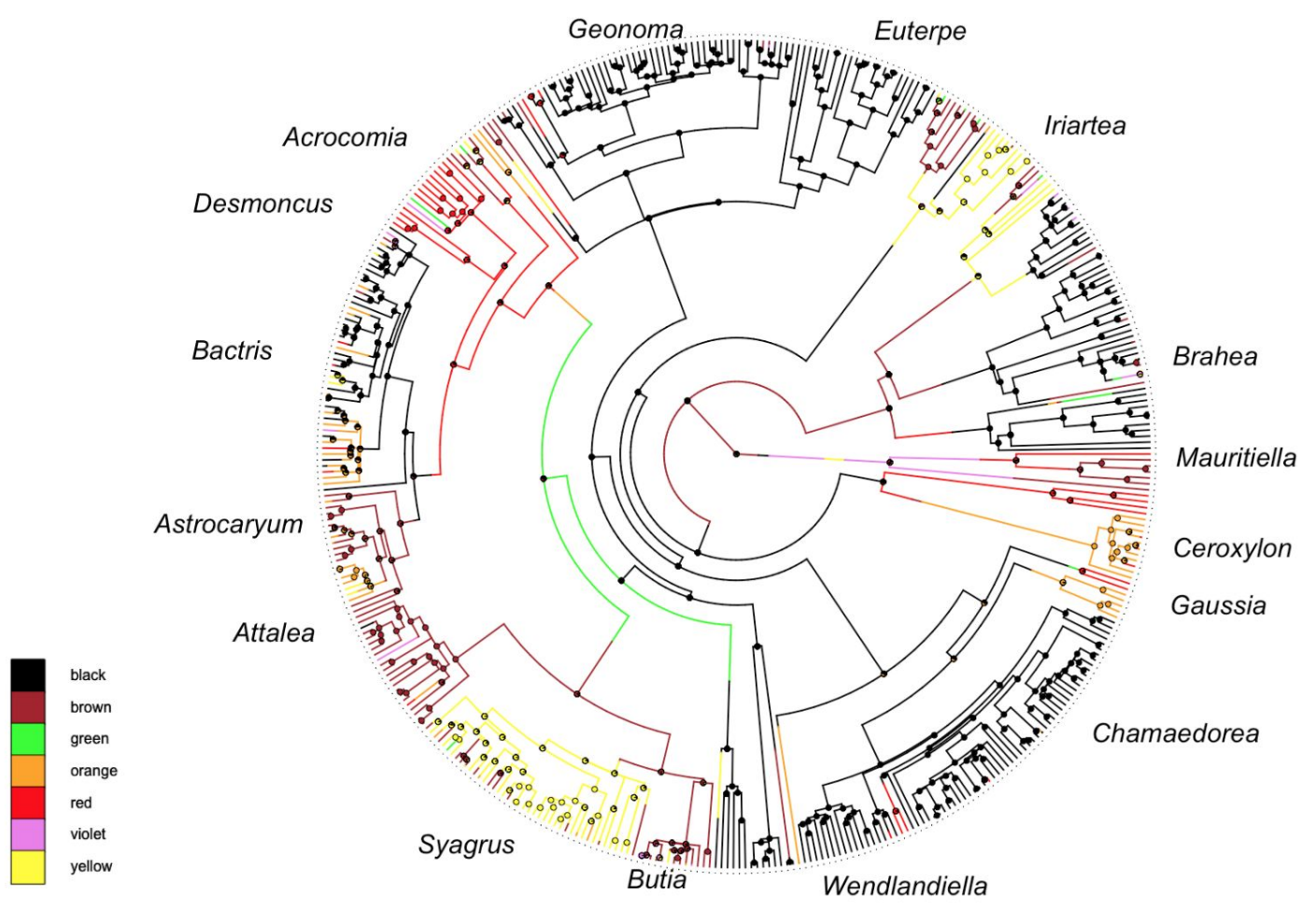


Figure 6. Reconstrução dos estados ancestrais da coloração dos frutos de palmeiras neotropicais. Os círculos indicam as estimativas dos estados marginais ancestrais. Alguns gêneros estão indicados nas pontas, como exemplo.

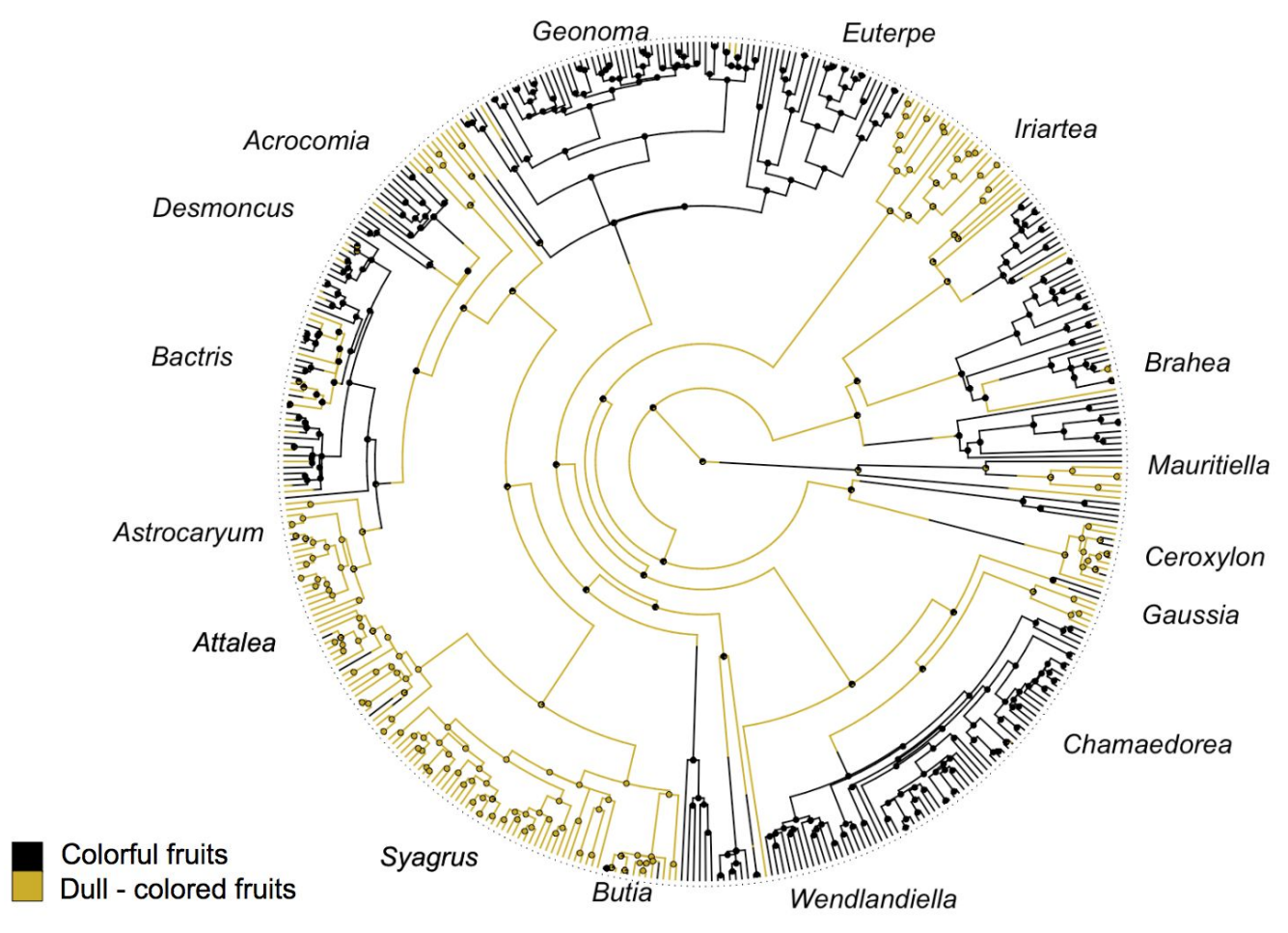

Figure 7. Reconstrução dos estados ancestrais da coloração dos frutos de palmeiras neotropicais. "Colorful fruits" se refere aos frutos com cores associadas a aves (preto, vermelho, violeta) e "Dull-colored fruits" se refere aos frutos com cores associadas a mamíferos (marrom, verde, amarelo, laranja). Os círculos indicam as estimativas dos estados marginais ancestrais. Alguns gêneros estão indicados nas pontas, como exemplo. 


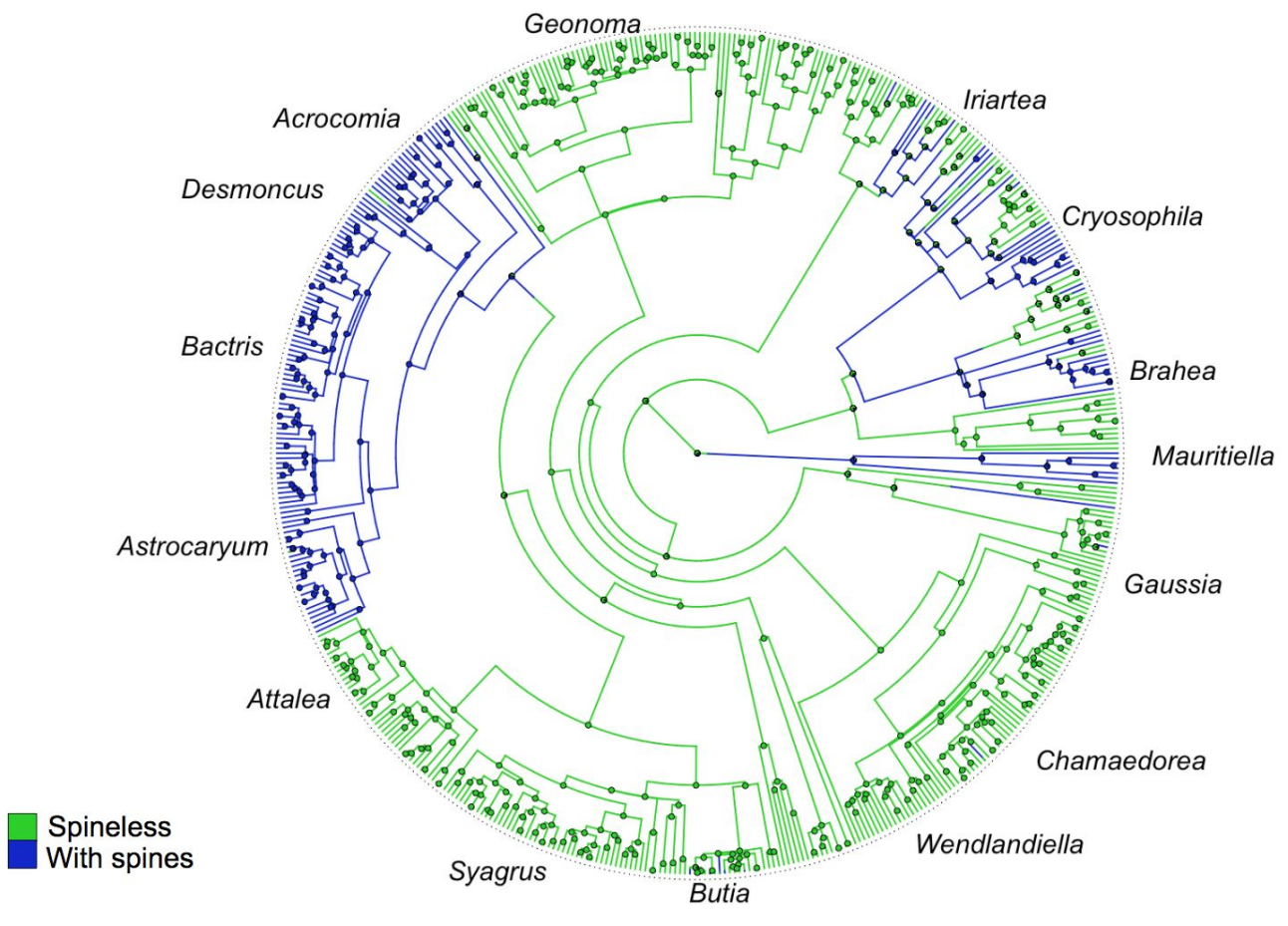

Figure 8. Reconstrução dos estados ancestrais de ausência (spineless) e presença (with spines) de espinhos em palmeiras neotropicais. Os círculos indicam as estimativas dos estados marginais ancestrais. Alguns gêneros estão indicados nas pontas, como exemplo.

Relacionando caracteres de espécies diferentes sem controlar pela história filogenética, podemos encontrar falsos positivos ou falsos negativos quanto às associações entre os caracteres das espécies. Deste modo, para investigar a relação entre tamanho de frutos e cores e tamanho de fruto e presença de espinhos faz-se necessário utilizar uma abordagem que controle o efeito da dependência entre os pontos devido a história compartilhada das espécies (Felsenstein 1985). Utilizando modelos lineares filogeneticamente controlados (pgls, Freckleton et al. 2002), encontrei que espécies com frutos com coloração relacionada a mamíferos tendem a ter frutos maiores do que espécies com frutos relacionadas a aves (figura 9). Além disso, espécies com espinhos tendem a ter frutos maiores do que espécies sem espinhos (figura 10), diferentemente de quando não controlamos pela história filogenética (Figura 4b). Esses resultados ilustram a importância de considerar as relações evolutivas entre táxons ao testar hipóteses sobre as relações entre caracteres. 

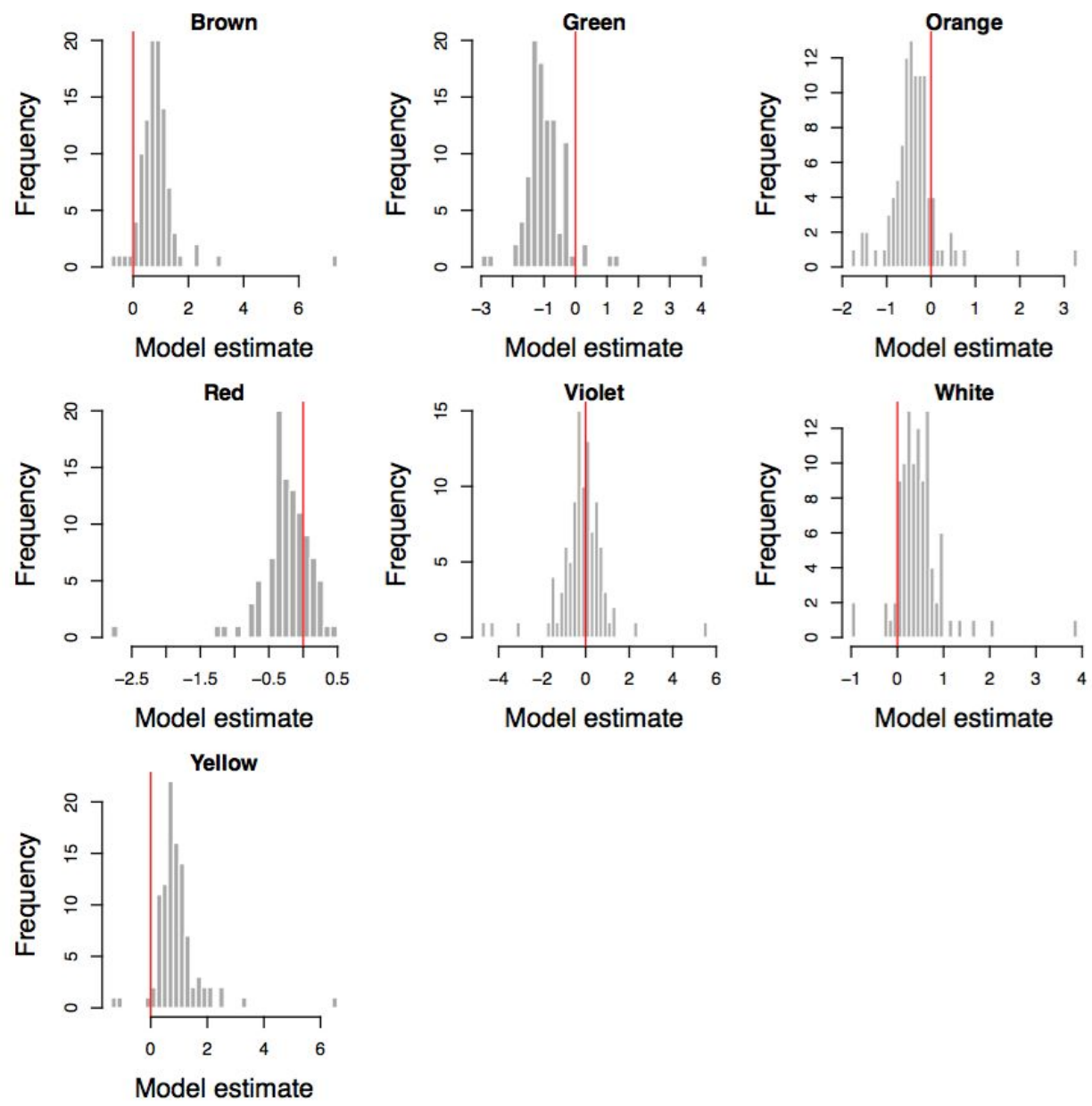

Figure 9. Distribuição do tamanho do efeito estimado da coloração dos frutos no comprimento dos frutos de acordo com as análises de PGLS. Valores positivos sugerem que palmeiras com frutos de uma dada cor possuem frutos maiores do que um estado usado como referencial (coloração preta) e valores negativos sugerem o contrário. A linha vertical indica o zero. Cada estimativa é um resultados de um teste independente considerando uma única filogenia (de um total de 100 filogenias). Efeitos positivos são muito mais frequentes do que esperado sob a hipótese nula para frutos marrons e amarelos, indicando que mesmo após controlar o efeito da inércia evolutiva, frutos com essas cores tendem a ser maiores em tamanho. 


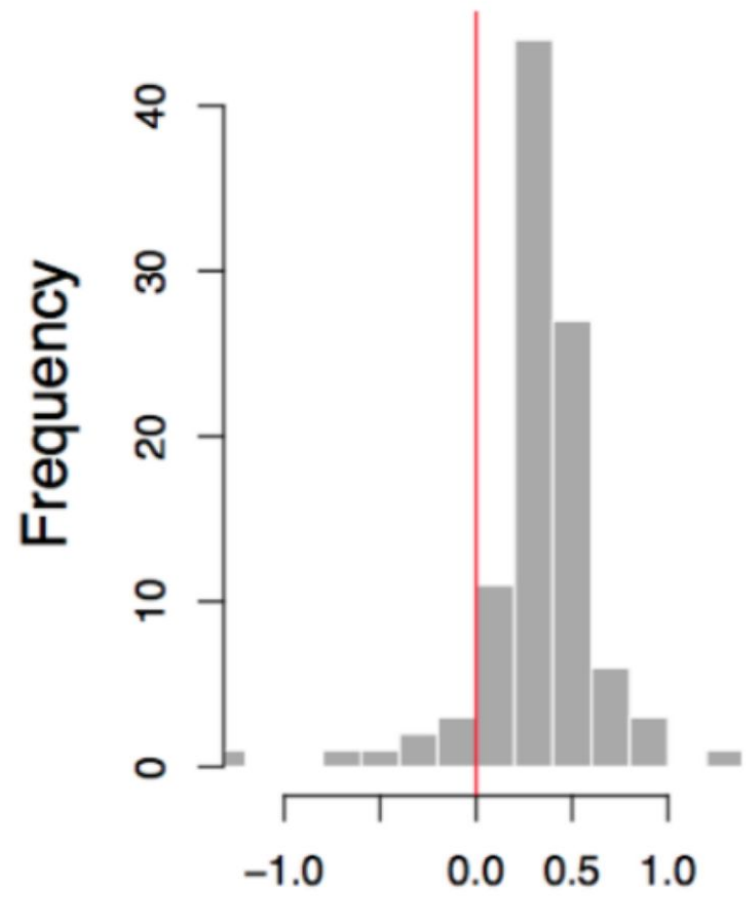

Model estimate

Figure 10. Distribuição do tamanho do efeito estimado da presença de espinhos no comprimento dos frutos de acordo com as análises de PGLS. Valores positivos sugerem que palmeiras com espinhos possuem frutos maiores que palmeiras sem espinhos e valores negativos indicam o contrário. A linha vertical indica o zero. Cada estimativa é um resultados de um teste independente considerando uma única filogenia (de um total de 100 filogenias). As análises mostram uma frequência muito maior de efeitos positivos do que negativos, indicando que após controlar o efeito da inércia evolutiva, há uma tendência em plantas com espinhos possuírem frutos maiores.

Essa fase de análises e resultados preliminares foi um momento muito importante no desenvolvimento desta dissertação. Nessa fase eu pude conhecer um pouco melhor sobre a história natural das palmeiras e desenvolver um pouco mais de intuição sobre o meu sistema de estudo. Além disso, eu me familiarizei com a literatura de frugivoria, herbivoria e métodos filogenéticos comparativos. Isso permitiu que eu desenvolvesse as ideias e organizasse o capítulo apresentado a seguir. Nesse capítulo apresento de forma mais detalhada como investiguei a história evolutiva de atributos de frutos e de defesas mecânicas 
em palmeiras com o objetivo de compreender o efeito de interações entre plantas e vertebrados em moldar caracteres de plantas. 


\section{Single chapter:}

\section{Associated evolution of fruit and defensive traits in Neotropical palms}

Lucas Ferreira do Nascimento ${ }^{1 *}$; Paulo R. Guimarães Jr ${ }^{2}$; Renske E. Onstein ${ }^{3}$; W. Daniel Kissling ${ }^{4}$ and Mathias M. Pires ${ }^{5}$

${ }^{1}$ Programa de Pós-graduação em Ecologia, Universidade de São Paulo, 05508-090, São Paulo, Brazil

${ }^{2}$ Departamento de Ecologia, Universidade de São Paulo, 05508-090, São Paulo, Brazil.

${ }^{3}$ German Centre for Integrative Biodiversity Research (iDiv) Halle-Jena-Leipzig, Deutscher Platz 5e, 04103 Leipzig, Germany.

${ }^{4}$ Institute for Biodiversity and Ecosystem Dynamics (IBED), University of Amsterdam, P.O. Box 94240, 1090 GE Amsterdam, The Netherlands.

${ }^{5}$ Departamento de Biologia Animal, Instituto de Biologia, Universidade Estadual de Campinas (UNICAMP), Campinas, 13083-862 Brazil

*Corresponding author: nascimento.flucas@gmail.com 


\section{Abstract}

Understanding how ecological interactions have shaped the evolutionary dynamics of species traits remains a challenge in evolutionary ecology. Combining trait evolution models and phylogenies, we analyzed the evolution of traits associated with seed dispersal (fruit size and color) and herbivory (spines) in Neotropical palms to infer the role of opposing animal-plant interactions in driving evolutionary patterns. We found that the evolution of fruit color and fruit size were associated in Neotropical palms, supporting the adaptive interpretation of seed-dispersal syndromes and highlighting the role of frugivores in shaping plant evolution. Furthermore, we reveal a positive association between fruit size and the presence of spines on palm leaves and stems. We hypothesize that interactions between palms and extinct large-bodied frugivores may explain the relationship between fruit size and spines. Large-bodied frugivores, such as extinct megafauna, besides consuming the fruits and dispersing large seeds, may also have consumed the leaves or damaged the plants, thus simultaneously favoring the evolution of large fruits and defensive structures. Our findings show how current trait patterns can be understood as the result of the interplay between antagonistic and mutualistic interactions that have happened throughout the evolutionary history of a clade.

Keywords: palms; seed-dispersal syndromes; spines; frugivory; herbivory 


\section{Resumo}

Entender como as interações ecológicas moldaram a dinâmica evolutiva dos caracteres das espécies continua sendo um desafio em ecologia evolutiva. Combinando modelos de evolução de caracteres e filogenias, nós analisamos a evolução de caracteres associadas à dispersão de sementes (tamanho e cor do fruto) e herbivoria (espinhos) em palmeiras neotropicais para inferir o papel das interações positivas e negativas entre plantas e animais na condução dos padrões evolutivos. Nós encontramos que o tamanho e a coloração dos frutos é evolutivamente correlacionada ao longo da história evolutiva das palmeiras neotropicais, suportando a interpretação adaptativa das síndromes de dispersão e destacando o papel de frugívoros em moldar caracteres de plantas. Além disso, nós encontramos uma associação positiva nas linhagens de palmeiras entre o tamanho de fruto e a presença de espinhos nas folhas e caule. Nós hipotetizamos que interações entre palmeiras e grandes mamíferos extintos podem explicar a relação entre tamanho de frutos e espinhos nas linhagens de palmeiras. Frugívoros de grande porte, como a megafauna extinta, além de consumir os frutos e dispersar sementes grandes, também podem consumir e/ou danificar outras partes da planta, favorecendo simultaneamente a evolução de grandes frutos e estruturas de defesa. Nossos resultados mostram como os padrões de caracteres atuais de um determinado clado podem ser entendidos como o resultado da interação entre interações antagonistas e mutualistas que aconteceram ao longo da história evolutiva do clado.

Palavras-chave: palmeiras; síndromes de dispersão de sementes; espinhos; frugivoria; herbivoria 


\section{Introduction}

Understanding how ecological interactions have shaped trait evolution in plants over time is a central challenge in evolutionary ecology (Strauss \& Irwin 2004). Animal-plant interactions, including mutualisms such as seed dispersal and antagonisms such as herbivory and seed predation, affect the fitness of individual plants. Seed dispersal by frugivores increases the fitness of plants by increasing the chances of seedling establishment on sites with high probability of survival (Wenny 2001) and reducing density-dependent and distance-dependent mortality of seedlings (Janzen 1970, Connell 1971). On the other hand, herbivory decreases the fitness of plants by reducing plant growth, survival or reproduction (Strauss \& Agrawal 1999). These fitness consequences at the individual level may scale up, affecting the macroevolutionary patterns and dynamics of plant traits within clades (Agrawal 2007, Serrano-Serrano et al. 2015, Onstein et al. 2017). Consequently, the extant morpho-physiological diversity that we observe in a given clade is affected not only by abiotic environmental factors but also by biotic pressures that acted over individuals, molding trait distributions in a clade over long timescales (Forest et al. 2007).

The evolution of fruit traits in particular, is thought to be highly responsive to interactions with frugivores. Different combinations of fruit size and color have been associated with the morphology and behaviour of different seed dispersers, forming seed-dispersal syndromes (Gautier-Hion et al. 1985, Janson 1983). Fruit size constrains the ingestion by frugivores, so that large fruits with large seeds are usually consumed by large-bodied species (Fuzessy et al. 2018). Fruit colors affect attractiveness and detectability, with conspicuous colors contrasting against the forest background (red, black and purple) being more attractive to frugivorous birds, whereas dull-colored fruits (green, yellow, brown and pale-orange) being often consumed by frugivorous mammals (Gautier-Hion et al. 1985; Janson 1983, Cazetta et al. 2009). Recent phylogenetic studies support seed-dispersal syndromes as an adaptive outcome of plant-vertebrate interactions (Lomáscolo et al. 2010a; Nevo et al. 2018b; Valenta et al. 2018). For instance, fruit size and fruit color of 64 fig species seem to have undergone correlated evolution as predicted by the seed-dispersal syndrome hypothesis (Lomáscolo et al. 2008). Additionally, studies have shown that fruit colors in forests of South Africa and Uganda versus forests of Madagascar 
seem to have evolved in response to interactions with different seed dispersers (Nevo et al. 2018a, Valenta et al. 2018, Voigt et al. 2004). Nevertheless, the support for the evolutionary interpretation of seed-dispersal syndromes as the result of selection by frugivores is mixed. Among fruit traits, fruit size seems to be more responsive to selection by frugivores than other traits (Jordano 1995). A recent macroevolutionary study has found that - across the Indo-Malay Archipelago - fruit size of $>400$ plant species was evolutionary related to bird and mammal diversity, but found no association between diversity and fruit colors (Brodie 2017). Accordingly, the evolution fruit colors may be affected by the evolution of other plant traits, such as leaf reflectance, constraining adaptive responses to seed dispersers (Burns et al. 2009). Thus, it remains unclear whether the evolutionary trajectories of fruit size and color covary within lineages and how general and widely applicable the adaptive signature of seed-dispersal syndromes is across clades and regions.

While fruit traits are mainly associated with seed-dispersal mutualisms, the evolution of defensive traits is primarily shaped by antagonisms. Mechanical defensive traits like spines and thorns are a widespread defense strategy of plants against mammalian herbivores (Grubb 1992), and leaves protected with spines tend to suffer less herbivory by mammals than unprotected ones (Cooper \& Owen-Smith 1986). Producing spines may constitute resource allocation costs to plants (Goheen et al. 2007), whereby resources that otherwise would be devoted to growth or reproduction are used to produce defensive structures. For example, in an exclusion experiment, Acacia individuals consumed by larger mammalian herbivores produced larger spines and less seed biomass than Acacia individuals that did not suffer attack by herbivores (Goheen et al. 2007). Similarly, palms in the Brazilian Pantanal have a higher density and larger spines in areas with cattle compared to areas free of cattle for 30 years, suggesting strong responses to megafauna herbivory by increasing investment in anti-herbivory defence (Göldel et al. 2016). Thus, defensive traits and fruits may be involved in a trade-off in energy allocation. If this trade-off is consistent over time it could leave a signature in macroevolutionary patterns, leading to a negative association between the presence of spines and fruit size in the evolutionary history of plant clades.

Alternatively, both fruit and defensive traits may respond to selection imposed by interactions with the same species. The same animal species can act as herbivore and seed disperser of a given plant, generating both negative and positive impacts on fitness. For example, African elephants are key seed dispersers for many plant species (Chapman et al. 
1992, Sekar \& Sukumar 2015), but they can also damage the plant by consuming vegetative parts or by breaking the branches and damaging the stem when reaching for the fruits (Owen-Smith 1992). The simultaneous allocation of resources into fruits that attract mammals and into defensive structures that deter them, may allow the plant to increase seed dispersal while protecting itself from being overexploited. Thus, over long timescales, the evolution of large fruits and defensive structures could have resulted in a positive association between the presence of spines and fruit size in the evolutionary history of certain plant clades.

Here, we study trait evolution of Neotropical palms (Henderson et al. 1997) to explore the evolutionary consequences of ecological interactions (frugivory, herbivory) in shaping the association between seed dispersal and defensive traits on plants. Palms are a characteristic element of tropical habitats (Couvreur \& Baker 2013). The palm family (Arecaceae) is a species-rich plant family with more than 2500 species worldwide, and has its highest species richness in the Neotropics and the Indo-Malayan region (Kissling et al. 2012). Palms show a great morphological diversity in fruits and seeds (Henderson et al. 1997) and are considered to be a keystone resource for frugivores in the tropics (Fleming \& Kress 2013). Palm seeds are dispersed by a wide range of frugivores, from small songbirds to elephants and tapirs (Muñoz et al. 2019, Zona \& Henderson 1989). Moreover, the taxonomic diversity of palms seems to have been influenced by fruit and seed size, with speciation being greater in lineages of small-fruited palms (Onstein et al. 2017) and extinction being more likely in large-seeded ones (Onstein et al. 2018). Another conspicuous feature of many palm species is the presence of spines (Henderson et al. 1997). Palms can have longs spines on the trunk, as well as smaller densely clustered spines in the bractea and leaves. Several papers on palms show that spinescence reduces herbivory by large mammals (Göldel et al. 2016; Beck 2006; Berry et al. 2008), suggesting that herbivory could have been an important selective force in the clade. Hence, palms are a suitable model system for testing how mutualistic and antagonistic plant-vertebrate interactions in tropical ecosystems have shaped the evolution of plant seed dispersal and defence traits.

In this study, we compiled a new, comprehensive dataset on Neotropical palm traits and used the most recent species-level palm phylogeny (Faurby et al. 2016) to examine the evolutionary regimes of fruit size, fruit color and spines, and to investigate whether certain trait states have been favored during the evolutionary history of the clade. We expected to 
detect associated evolution of fruit traits (fruit size and fruit color) related to seed-dispersal syndromes, so that small fruits and fruit colors related to frugivory by birds would be evolutionarily linked, whereas large fruits would be associated with dull-colors as they are predominantly consumed by frugivorous mammals. Additionally, we expected to find an association between the evolution of fruit traits and defensive traits. A negative association between fruit size and the presence of spines could be related to resource-allocation trade-offs. Alternatively, a positive association between the presence of spines and fruit size could be the result of interactions with partners that had both positive (through seed-dispersal mutualisms) and negative effects (through herbivory) on fitness, such as mega-herbivores.

\section{Material and methods}

\section{Data on fruit size, fruit color and spines}

We built a dataset on palm traits using information from the literature, mainly based on Henderson et al. (1997) and Lorenzi et al. (2010). We systematically searched the literature for information on fruit size, fruit color, and spines for those palm species that were not present in the two key references. We did not consider hybrids and subspecies, identified according to The Plant List (http://www.theplantlist.org), in our analyses. We also excluded Cocos nucifera from our analyses because this species is exotic to the Neotropics, and it is not dispersed by animals (Baudouin \& Lebrun 2009), besides being clearly an outlier in terms of fruit size. In total, our dataset comprises information on fruit color for 434 palm species and for spines and fruit size on 530 out of the approximately 550 species estimated for the Neotropical region (Henderson et al. 1997). We used fruit length as proxy for fruit size in our analyses. Using only one dimension is enough to characterize fruit size in palms because most fruits are approximately round in shape. In most plants, seed size may be the factor constraining consumption by seed dispersers. Palms, however, are mainly single seeded or, when having multiple seeds, the seeds are often within the same diaspore. Moreover, several previous studies have demonstrated a positive correlation between fruit and seed size in fleshy-fruited plants (Alcántara \& Rey 2003, Jordano 2000), especially for 
single or few seeded fruits (Jordano 1995b, Sallabanks 1993). Thus, we reasonably assume a strong correlation between fruit size and seed size in Neotropical palms. We classified the species according to the predominant color in the mature fruit. For our analysis, we classified the fruits as "colorful fruits" (red, black and purple) and "dull-colored fruits" (green, yellow, brown and orange), reflecting colors that have been related to bird and mammal frugivory, respectively (Gautier-Hion et al. 1985, Nevo et al. 2018a). Finally, we classified all species according to the presence ("with spines") and absence of spines ("spineless"). We consider spines to be any stiff sharply pointed structure (Grubb 1992) that is present either at the stem, peduncular bract, rachis or petioles, which is often associated with defense specifically related to mammalian herbivory (Charles-Dominique et al. 2016; Grubb 1992).

\section{Phylogenies and phylogenetic uncertainty}

We used a recently compiled species-level phylogeny of palms (Faurby et al. 2016) for comparative analyses. Faurby et al. 2016 constructed a variety of time-calibrated super-trees using a Bayesian approach, morphological constraints and the Govaerts et al. (2011) taxonomy including genetic and morphological data of all 184 genera of palms. Here, we performed the analyses with sets of phylogenetic trees using the constraints and the Govaerts et al. (2011) taxonomy because it takes into account previous morphological knowledge contained in taxonomic information (constraints) and the most up to date world checklist of Arecaceae (Govaerts et al. 2011). To deal with phylogenetic uncertainty, we

performed all phylogenetic analyses with 100 equally likely randomly sampled trees, and built distributions for each parameter estimate. In our analyses, we pruned out species of the trees of Faurby et al. (2016) that we did not have trait information on fruit traits and presence of spines.

\section{Ancestral state reconstructions and evolutionary trait regimes}

To have a better understanding of the evolution of fruit and defensive traits, we performed simulations of ancestral state reconstruction of fruit color and presence/absence of spines in Neotropical palms. We used stochastic character mapping (Revell 2012) to reconstruct the 
evolutionary history of these traits on the phylogenies of Neotropical palms. Each ancestral state reconstruction arises from the combination of multiple simulations for a given phylogeny, thus incorporating uncertainty on the reconstruction itself (Revell 2012). To incorporate the uncertainty related to the phylogeny we ran ancestral state reconstructions for each of the 100 randomly sampled phylogenies and compared the estimated root state (the proportion of simulations assigning the root a given state).

To further investigate the evolutionary trait regimes (i.e. gains and losses) of fruit color and spines we fitted macroevolutionary models to the 100 palm phylogenetic trees using a likelihood approach for model selection. We used the "fitDiscrete" function in the "geiger" R package (Harmon et al. 2008), and compared the fit of two state transition models: (1) the equal-rate (ER) model, which assumes transition rates from one state to the other to be symmetric; and (2) the all-rates different (ARD) model which allows transition rates between states to differ. This step of fitting trait evolution models to the phylogenies allowed us to obtain insights into the evolutionary trends (transition rates) of each trait for the clade as a whole.

\section{Evolutionary relationship between fruit length, fruit colors and spines}

To investigate the evolutionary relationship between (1) fruit length and fruit color, and (2) fruit length and the presence of spines we used a maximum likelihood approach implemented in the "OUwie" R package (Beaulieu \& O'Meara 2016). The OUwie function uses trait data for the tips of the species-level phylogeny to infer the evolutionary dynamics of continuous traits (fruit size) while considering ancestral reconstructions of categorical traits (i.e. presence/absence of spines and fruit color). Brownian motion (BM) models assume trait evolution occurs through a random walk governed by the evolutionary rate parameter $\sigma^{2}$. The Ornstein-Uhlenbeck (OU) models assume a constrained random walk where trait values change towards an optimum $\theta$ with strength of selection a (Hansen 1997). We fitted seven evolutionary models derived from BM and OU models (table 1) to estimate parameter values that best describe the evolution of fruit length given the phylogeny and each ancestral state reconstruction (e.g. Alencar et al. 2017, Onstein et al. 2016). These models differ in how the rate of evolution, evolutionary optima, and strength 
of selection are allowed to vary, thus differing in their assumptions on how fruit color or the presence/absence of spines could have affected the evolution of fruit length (table 1).

For both the analyses on the evolutionary relationship between fruit length and colors or spines we considered 10 ancestral state reconstructions for each of the 100 phylogenies, totalling 1000 ancestral state reconstructions. After performing the OUwie analyses, we checked if the estimated $\theta$ for the fitted reconstructions were biologically feasible and if the eigenvalues of the Hessian matrix were negative (Beaulieu \& O'Meara 2016), indicating that the model failed in obtaining reliable parameter estimates. We excluded fitted reconstructions with negative eigenvalues of the Hessian matrix and those which returned very unrealistic fruit size optima $(\theta>20 \mathrm{~cm}$ or $<0.1 \mathrm{~cm})$. We also excluded statistical outliers, for the remaining parameters, since these may be produced when the model fails in converging (Alencar et al. 2017). Because OUMA and OUMVA models often failed to converge we report the results for the remaining models and present the results for OUMA and OUMVA in the Supplementary material. For the remaining models only 20 of the 1000 reconstructions showed convergence problems. Thus we report results for a total of 980 reconstructions.

We used the Akaike information criterion corrected for small sample sizes (AICc) to identify the model with the greatest fit to the trait distribution in the phylogenies (Anderson $\&$ Burnham 2002). For each fitted reconstruction we calculated the $\triangle \mathrm{AICc}$ (the difference between AICc values for each model and the lowest AICc value among all models) and considered a model was supported if the difference of $\triangle \mathrm{AICc}$ between models was greater than two. Additionally, we calculated the relative support for each model using Akaike weights $\left(w_{i}\right) ; w_{i}$ varies from 0 (no support) to 1 (best model).

If there is an evolutionary relationship between fruit length and fruit color, as suggested by the syndrome hypothesis, then we should expect the favored models to be those with different evolutionary optima for fruit length on palm lineages differing in fruit color, with a larger optimum in lineages with dull-colored fruits. Similarly, if the evolution of fruit size and spines had any association, models with different optima for fruit length should be favored for the analyses considering spinescence. One particular genus of spineless palms with very large seeds, Attalea, significantly raises the mean size of fruits in palms without spines. To understand how this genus affects the obtained results we 
performed a sensitivity analysis by removing Attalea from the phylogeny and rerunning the analyses (see Supplementary material) .

Table 1: Description and interpretation of the fitted evolutionary models. The evolutionary scenarios refers to lineages with differents states of color fruit (colorful or dull colored) and spines (with spines or spineless).

\begin{tabular}{|c|c|c|}
\hline $\begin{array}{l}\text { Evolutionary } \\
\text { models }\end{array}$ & Description & Implications to trait association \\
\hline BM1 & single-rate BM model & $\begin{array}{l}\text { no association between fruit size and } \\
\text { the evolutionary scenarios }\end{array}$ \\
\hline BMS & $\begin{array}{l}\text { multi-rate BM model, which } \\
\text { allows } \sigma^{2} \text { to differ among lineages } \\
\text { with different states for each } \\
\text { evolutionary scenario }\end{array}$ & $\begin{array}{l}\text { no association between fruit size and } \\
\text { the evolutionary scenarios }\end{array}$ \\
\hline OU1 & OU model with a single optimum & $\begin{array}{l}\text { no association between fruit size and } \\
\text { the evolutionary scenarios }\end{array}$ \\
\hline OUM & $\begin{array}{l}\text { OU model allowing distinct } \theta \text { for } \\
\text { each evolutionary scenario }\end{array}$ & $\begin{array}{l}\text { association between fruit size and } \\
\text { the evolutionary scenarios }\end{array}$ \\
\hline OUMV & $\begin{array}{l}\text { OU model allowing different } \sigma^{2} \\
\text { and } \theta \text { for each evolutionary } \\
\text { scenario }\end{array}$ & $\begin{array}{l}\text { association between fruit size and } \\
\text { the evolutionary scenarios }\end{array}$ \\
\hline OUMA & $\begin{array}{l}\text { OU model allowing different } \alpha \text { and } \\
\theta \text { for each evolutionary scenario }\end{array}$ & $\begin{array}{l}\text { association between fruit size and } \\
\text { the evolutionary scenarios }\end{array}$ \\
\hline OUMVA & $\begin{array}{l}\text { OU model allowing different } \sigma^{2}, \alpha \\
\text { and } \theta \text { for each evolutionary } \\
\text { scenario }\end{array}$ & $\begin{array}{l}\text { association between fruit size and } \\
\text { the evolutionary scenarios }\end{array}$ \\
\hline
\end{tabular}




\section{Results}

Fruit length of Neotropical palms varies from $0.4 \mathrm{~cm}$ to $12.5 \mathrm{~cm}$ with the majority $(63 \%)$ being smaller than or equal to $2 \mathrm{~cm}$ (figure 1). Regarding fruit color, 177 palm species (41\%) have dull-colored fruits and 257 (59\%) have colorful fruits, with both states being widely distributed in the phylogeny. Spines are present in 164 palm species (31\%), whereas $366(69 \%)$ are spineless. Spines are mainly found in one large clade including the palm genera Acrocomia, Astrocaryum, Bactris, and in an early-diverging clade containing Mauritiella and Mauritia. Of the 61 genera present in our dataset, 26 have species with spines (43\%), in 35 genera all species are spineless (57\%), 38 have species with dull-coloured fruits (62\%), and 33 have species with colorful fruits (54\%).

\section{Ancestral state reconstruction and evolutionary trait regimes}

According to the reconstructions, colorful fruits and spineless palms were the most likely root ancestral states (figure 2-3), compared to dull-colored fruits and presence of spines, respectively. In all reconstructions, there was an early emergence of dull-colored fruits in lineages of Mauritiella, but dull-colored fruits evolved later in other clades that also present large fruits (figure 2). There was also an early emergence of spines in lineages of Mauritiella, but spines evolved again in the clade that comprises the genera Acrocomia, Desmoncus, Bactris and Astrocaryum (figure 3).

For both fruit color and the presence of spines, we found strong support for the model assuming equal transition rates between states (ER), indicating no differences in the rates of transition from colorful fruits to dull-colored fruits and vice-versa $\left(\mathrm{AICc}_{\mathrm{ER}}<\right.$ $\mathrm{AICc}_{\mathrm{ARD}}$ for $94 \%$ of the phylogenies, table S1) and no differences in transition rate between gaining or losing spines $\left(\mathrm{AICc}_{\mathrm{ER}}<\mathrm{AICc}_{\mathrm{ARD}}\right.$ for $89 \%$ of the phylogenies, table $\mathrm{S} 2$ ). This result suggests that there was no consistent trend on developing colorful or dull-colored fruits nor in acquiring or losing spines. The mean estimated transition rates between dull-colored and colorful fruits for all phylogenies $(0.015 \pm 0.001$, table S3) was twice as 
large as the estimated transition between spineless and spine-bearing lineages $(0.007 \pm$ 0.0004 , table S4).

\section{Evolutionary relationship between fruit length, fruit colors and spines}

A model where fruit size had different optima and evolutionary rates (OUMV) for lineages with different fruit colors had the strongest support for all analyzed phylogenies (980). (figure 4.A - B ). The estimated optimum values $(\theta)$ consistently indicated that larger fruits tended to be favored on lineages with dull-colored fruits (mean $=3.38 \mathrm{~cm}$ ) compared to lineages with colorful fruits (mean $=1.39 \mathrm{~cm})$ (figure $4 . \mathrm{A}-\mathrm{B})$. For most of the fitted reconstructions, the evolutionary rate parameter $\left(\sigma^{2}\right)$ was smaller for lineages with colorful fruits than for lineages with dull-colored fruits (figure S.1), suggesting higher stochasticity in fruit size evolution in lineages with dull-colored fruits.

We also found greater support for models assuming different evolutionary regimes of fruit size for lineages with and without spines (OUMV had the best fit for 758 out of 980) phylogenies) (figure 4.C - D). The estimated optimum values $(\theta)$ consistently indicated that fruit sizes tend to be larger for lineages with spines (mean $=2.51 \mathrm{~cm})$ compared to lineages without spines $($ mean $=2.12 \mathrm{~cm})$ (figure 4.C - D). Differences in the other parameter $\left(\sigma^{2}\right)$ between the lineages with spines and spineless did not show a consistent trend across replicates (figure S.2).

The sensitivity analysis to understand how Attalea affects the obtained results shows that the difference in the mean fruit size optima between lineages with and without spines increases considerably when removing Attalea $(2.5 \mathrm{~cm}$ vs $1.8 \mathrm{~cm}$, respectively; figure S.3 4). 

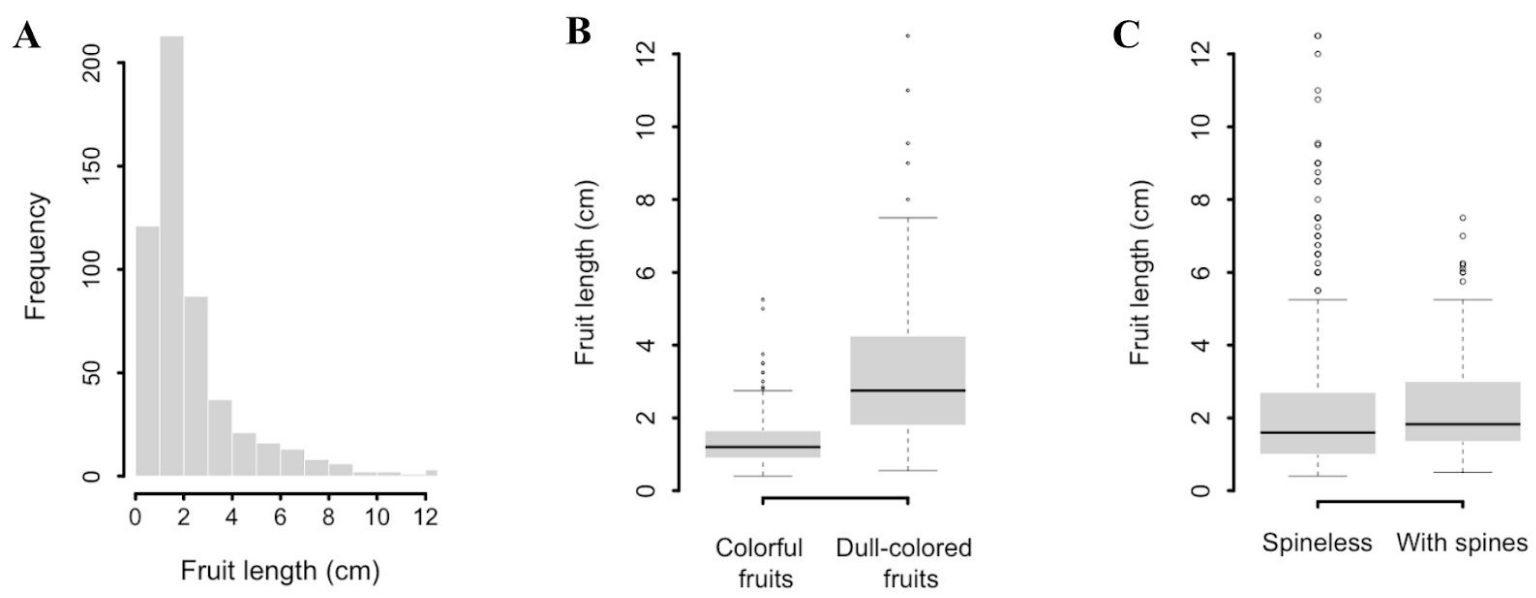

Figure 1: (A) Frequency distribution of fruit sizes in Neotropical palms ( $n=530$ species). (B) Length of fruits $(\mathrm{cm})$ as a function of colourful vs. dull-colored fruits $(\mathrm{n}=434$ Neotropical palm species). (C) Length of fruits $(\mathrm{cm})$ as a function of the presence or absence of spines. (B - C) Black horizontal lines indicate the medians. The whiskers extend to the data point which is no more than 1.5 times the interquartile range from the box.

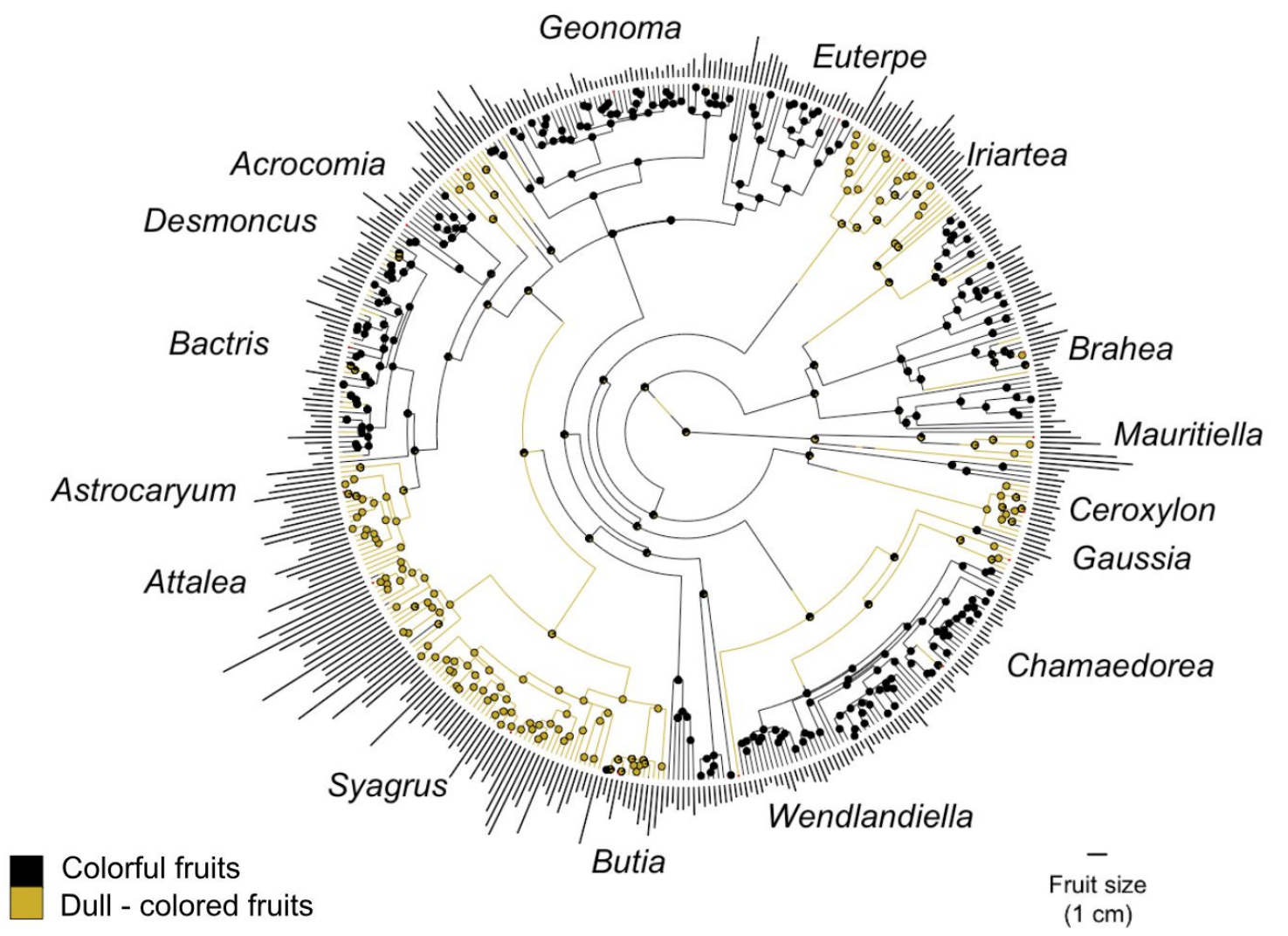

Figure 2: Reconstruction of ancestral states for fruit color in Neotropical palms from stochastic character mapping (100 simulations). Yellow branches indicate dull-colored fruits 
in a given lineage and black branches indicate colorful fruits. Bars in the tips indicate the fruit length. The circles indicate the distribution for estimates of the marginal ancestral states. Examples of representative palm genera are indicated at the tips.

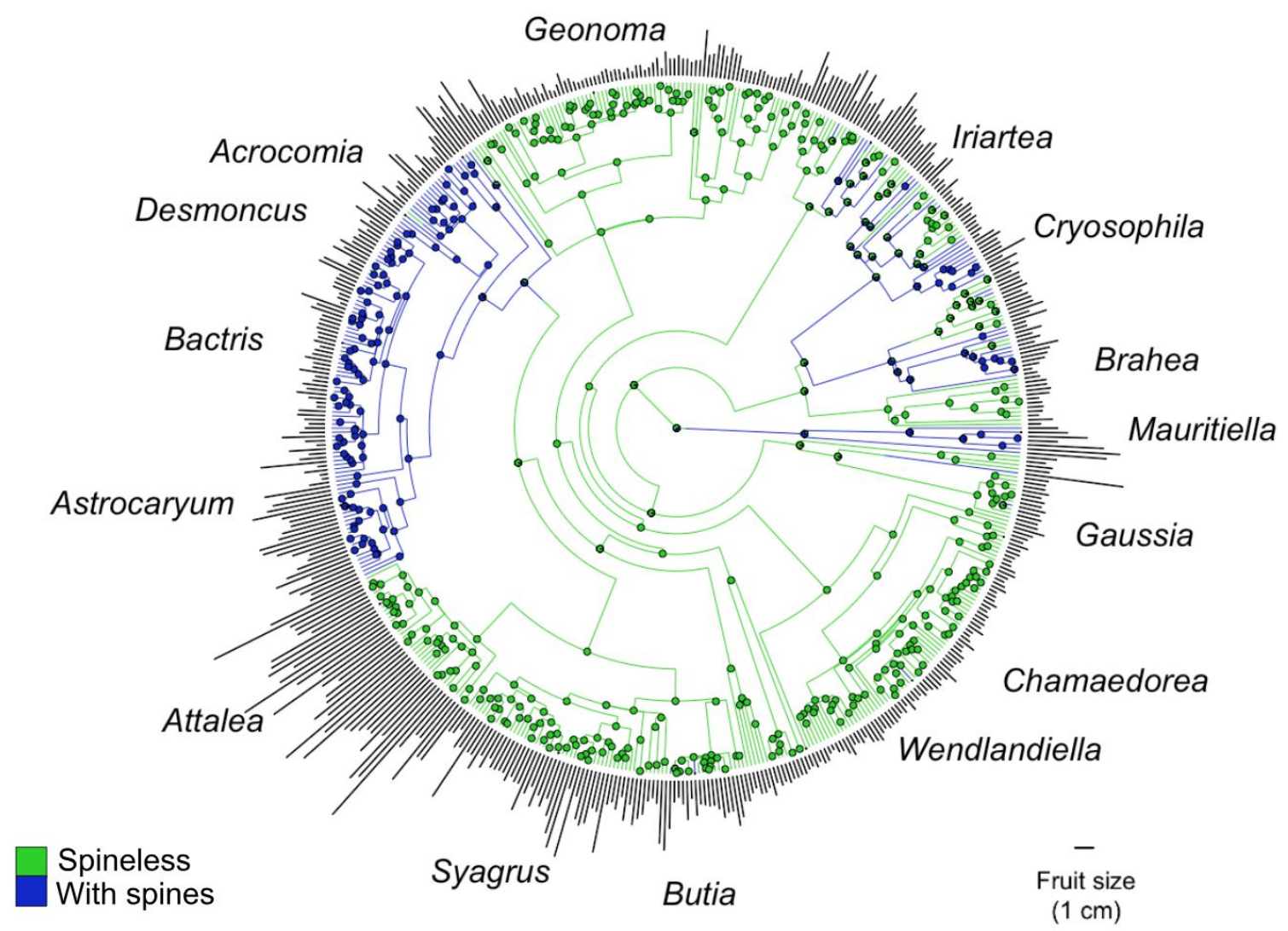

Figure 3: Reconstruction of ancestral states for spines in Neotropical palms from stochastic character mapping (100 simulations). Blue branches indicate the presence of spines in a given lineage and green branches indicate the absence of spines. Bars in the tips indicate the fruit length. The circles indicate the distribution for estimates of the marginal ancestral states. Examples of representative palm genera are indicated are the tips. 
A

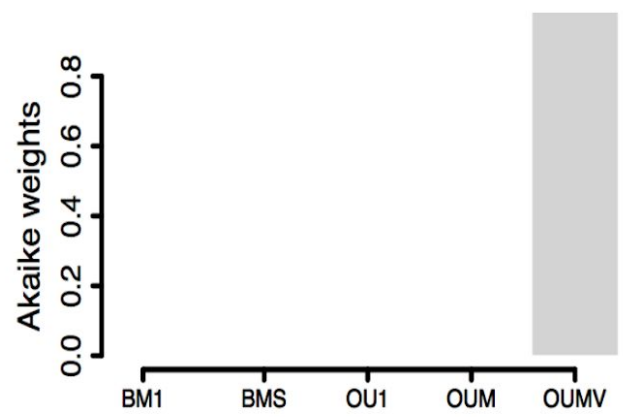

C

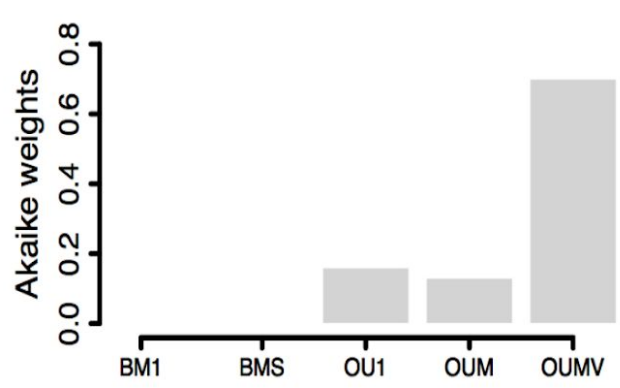

B
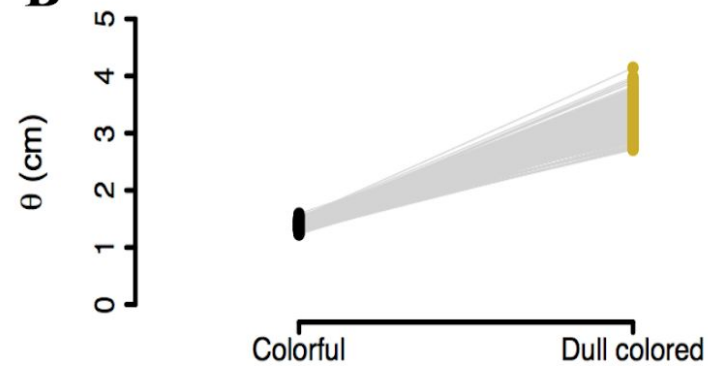

D

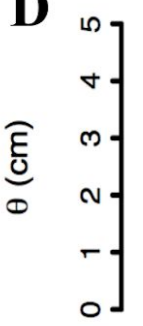

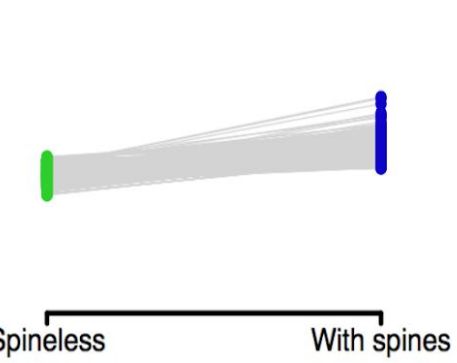

Figure 4. The evolution of fruit traits and spines in Neotropical palms. (A) Akaike weights and (B) evolutionary optimum fruit size $(\theta)$ estimated for fruit length in lineages with colorful fruits and dull-colored fruits. (C) Akaike weights and (D) evolutionary optimum fruit size $(\theta)$ estimated for fruit length in lineages with spines and spineless. The OUMV model had the best fit for both analysis. The $\theta$ values estimated for fruit length were larger (B) in lineages with dull-colored fruits than lineages with colorful fruits and (D) in lineages with spines than lineages without spines. Each line in B and D is one fitted reconstruction out of 900 .

\section{Discussion}

We used species-level phylogenies and trait evolution models to investigate the macroevolutionary history of fruit and defensive traits of Neotropical palms. We found that the most recent ancestor of all Neotropical palms most likely had colorful fruits and no spines with no consistent trend favoring the evolution of colorful or dull-colored fruits, neither for acquiring or losing spines over the evolutionary history of the clade. Our results support the adaptive interpretation of seed dispersal syndromes, by showing an evolutionary association between fruit size and fruit color. Moreover, our results indicate that the 
evolution of spines is positively related to the evolution of large fruits in palm species, suggesting that frugivores could have had both positive (through seed-dispersal mutualisms) and negative effects (through herbivory) during the evolutionary history of this plant clade.

Fruit size seems to have evolved towards a mean size around $2 \mathrm{~cm}$ in Neotropical palms and the good fit of OU models support a scenario of constrained evolution (Arnold 1992, Futuyma 2010). Previous work, analyzing 910 species across 94 plant families has shown that fruit diameter is the main fruit trait responding to interactions with animals (Jordano 1995). Although large-bodied frugivores can consume fruits and disperse seeds of different sizes, smaller-sized seed dispersers, such as most bird species, are limited by gape size in what they can consume, imposing selective pressures that may constrain the evolution of large fruits (Galetti et al. 2013). Conversely, if fruits and their seeds are too small, germination may be compromised because small seeds have less reserves and are less resistant to desiccation (Parolin 2000, Galetti et al. 2013). Consequently, the evolution of fruit and seed size is likely the result of both abiotic selective pressures that favor larger sizes, and selective pressures imposed by small seed dispersers that will often select against large sizes. Our analyses indicated that the evolution of fruit size in Neotropical palms was also influenced by the evolution of fruit color and spinescence, suggesting that the macroevolutionary dynamics of fruit traits may be the result of a complex interplay between positive and negative fitness effects resulting from disparate ecological interactions.

We found that the macroevolutionary dynamics of fruit sizes vary among lineages with fruits of different colors. In those lineages with colorful fruits, usually preferred by frugivorous birds, evolution seems to have favored smaller-sized fruits, whereas dull-colored fruits evolved towards larger sizes. This result lends support to the adaptive hypothesis of seed-dispersal syndromes (Gautier-Hion et al. 1985, Janson 1983), corroborating recent results for other plant clades that found multiple fruit traits, including colour, to evolve in response to selective pressures exerted by seed dispersers (Lomáscolo et al. 2010b, Nevo et al. 2018a, Nevo et al. 2018b). Macroecological differences in the distribution of fruit sizes have been associated with variation in the composition of frugivore assemblages in different regions, with plants with larger fruits being more common in regions where the richness of large mammalian frugivorous is greater (Brodie 2017, Lord 2004). Accordingly, differences in the composition of seed-disperser assemblages across the Neotropics may have generated and maintained this relationship over time. Fruit size has 
been shown to be more responsive to plant-frugivore interactions than other traits, including fruit color (Brodie 2017), leading some to argue against the evolutionary interpretation of syndromes (Burns et al. 2009, Schmidt et al. 2004, Willson \& Whelan 1990). Our results indicate that, at least in Neotropical palms, fruit size and fruit colors evolved in consort over long time scales. One possibility for the mixed conclusions in the literature is that the evolutionary relationship among fruit traits that comprise seed-dispersal syndromes is pronounced within certain clades, but is not consistent across multiple clades that differ in their dependence on interactions with seed dispersers and in their potential to respond to selection, i.e., facing different levels of evolutionary constraints.

Beyond the fruit size-colour relationship, our analysis also indicates that fruits evolved towards larger sizes in lineages with spines when compared to lineages without spines, showing an evolutionary relationship between reproductive and defensive traits in Neotropical palms. Fruits being larger in palm lineages with spines suggests that there is no signature at the macroevolutionary scale of trade-offs in resource allocation related to defense and reproduction in Neotropical palms. The evolution of fruit size is largely responsive to frugivores (Jordano 1995), whereas defensive traits respond to antagonists such as herbivores (Agrawal 2007, Goheen et al. 2007) and seed predators (Bodmer 1991, Rodgerson 1998). Selective pressures from the two opposing types of interactions acting together could explain the relationship between spines and fruit size. Although the difference in the mean of estimated evolutionary trait optima for plants with and without spines may be seen as small $(2.6 \mathrm{vs} 2.1 \mathrm{~cm})$, such small differences in fruit size can be enough to filter out several frugivores as potential seed dispersers. Fruits larger than $2 \mathrm{~cm}$ are too large for most of the avian frugivores in the Neotropics (Galetti et al. 2013) and can only be consumed by large-gaped frugivores such as mammals and some large bird species (e.g., toucans, rheas, guans, and fruitcrows). Interactions with large frugivores, especially mammals, can be beneficial and harmful for the plant at the same time. Large mammals can disperse large amounts of seeds and provide long-distance seed dispersal (Jordano 2017, Pires et al. 2018), but may also damage the plant when scratching, browsing or when reaching for fruits (Owen-Smith 1992). Spines have been shown to be efficient in reducing the damage done by browsers (Milewski et al. 1991) and the rates of biomass ingestion by herbivores (Belovsky et al. 1991). Moreover, although mammals often consume ripe fruits that have fallen from the plant, large mammals may reach and consume fruits before they 
have ripened. Many palms have chemical defenses that can discourage consumption of unripe fruits, when the embryo is not ready for germination (Tomlinson 1990). Palm spines could act in the same direction, reducing damage of vegetative parts, but also impeding early consumption of fruits and seeds, which are vulnerable until the fruits ripen (Smythe 1989).

Neotropical palms evolved in an ecological context where mammalian assemblages were rich in large-bodied species, before the Late Quaternary Extinction episode (Janzen and Martin 1982, Guimarães et al. 2008). Therefore, certain observed characteristics of fruits and defenses could be "anachronic", i.e., traits shaped by extinct interactions (Janzen and Martin 1982). Illustrative examples of palms with fruit and defensive traits that have been considered anachronic are Astrocaryum aculeatissimum from the Brazilian Atlantic forest and Acrocomia aculeata from the Brazilian Cerrado and other open habitats, both species with long spines and large fruits $(\geq 4 \mathrm{~cm})$, and whose seeds are currently dispersed by scatter-hoarding rodents or domestic cattle (Galetti et al. 2006, Göldel et al. 2016). Interactions with large mammals from the past would have allowed large fruits to evolve, but could also have favored the evolution of defenses, thus generating the observed association between spines and large fruits. Knowing that fruit size can evolve fast in response to changes in frugivore assemblages (Galetti et al. 2013) and that the size and density of palm spines can respond to interactions with large mammals (Göldel et al. 2016), it is also plausible to assume that the relationship between fruit size and spines that we found could have been more pronounced in the past, and microevolutionary changes reducing fruit size have reduced the discrepancy.

Another hypothesis that could explain the evolution of large fruits in plants with spines is that the evolution of both large fruits and spines responded to seed predators. Producing large fruits and seeds is costly for the plant (Goheen et al. 2007), but large seeds often have a greater chance of germination (Galetti et al. 2013; Gómez 2004). Seed predation can significantly impact fitness (Gómez 2004; Orrock et al. 2006) and plants that invest on producing large seeds also invest in defending them against predation. For example, the seeds of the Amazonian palm Oenocarpus bataua is protected with a bundle of fibrous lignin that reduces seed predation by ungulates on large seeds (Bodmer 1991). Similarly, the evolutionary relationship between fruit size and presence of spines could be a response to seed predation pressure by vertebrates, especially rodents such as squirrels, 
which often consume palm seeds. However, even though the effectiveness of spines in preventing seed predation has not been systematically investigated, the spiny trunks of Astrocaryum spp. do not seem to be enough to prevent the access of squirrels to fruits and seeds (Palmer \& Koprowski 2014). If spines are not effective in preventing seed predation by rodents in the present, then the hypothesis that these interactions are the underlying cause for the evolutionary association between fruit size and spines is less plausible.

A sensitivity analysis where we removed the genus Attalea from the phylogeny and re-ran the analysis testing the relationship between fruit size and presence of spines, showed that without considering this genus the difference in evolutionary optima of fruit size is much more pronounced (Figure S.6). Attalea fruits and seeds are very large and the seeds which have a thick and hard protective coat that reduces predation by beetles, small rodents (Silvius 2005) and parrots - are mainly dispersed by scatter-hoarding rodents rather than large mammals (Dracxler \& Forget 2017). Trait evolution in Attalea may have been strongly influenced by interactions with scatter-hoarding rodents and less influenced by interactions with other groups such as large-bodied frugivores. Moreover, Attalea, and other palms, may rely on other defensive strategies against seed predators and herbivores including chemical defenses and resprouting (Liesenfeld \& Vieira 2018). We focused on spines, which have a well-established function as a defensive trait, to examine possible effects of antagonisms on macroevolution patterns of trait evolution. Future work could investigate the relationship between fruit size and other defensive strategies besides spines in Neotropical palms and other plant groups.

Interactions between frugivores and angiosperms have a long history, of at least 80 million years (Eriksson 2016). Phylogenetic and fossil evidence suggest that these interactions had a major influence on the evolution and diversification of several plant and animal clades (Gómez \& Verdú 2012, Burin et al. 2017), including palms (Onstein et al. 2017, Onstein et al. 2018). Phylogenetic comparative methods can help us to understand how this long history of plant-vertebrate interaction affected trait evolution (Cornwell and Nakagawa 2017). We used different macroevolutionary models to shed light on the evolution of reproductive and defensive plant traits. By exploring the relationship between fruit size, fruit color, and defensive traits, our analyses suggests that the interplay between mutualisms and antagonisms affected the macroevolutionary dynamics of Neotropical palm traits. Future studies could investigate whether similar patterns occur in other clades, and 
whether these patterns are replicated in different geographic regions (e.g. Afrotropics, South-East Asia) and across spatial and temporal scales.

\section{Acknowledgements}

We thank Mauro Galetti and Marco A Pizo for comments and suggestions and Gustavo Burin and Laura Alencar for help with analyses.

\section{Funding}

This study was financed in part by the Coordenação de Aperfeiçoamento de Pessoal de Nível Superior - Brasil (CAPES) - Finance Code 001. L.F.N. was supported by CNPQ (Conselho Nacional de Desenvolvimento Científico e Tecnológico). P.R.G is supported by FAPESP (2017/08406-7) W.D.K. acknowledges financial support from the Netherlands Organization for Scientific Research (824.15.007). R.E.O. acknowledges the support of the German Centre for Integrative Biodiversity Research (iDiv) Halle- Jena-Leipzig funded by the Deutsche Forschungsgemeinschaft (DFG, German Research Foundation)_FZT 118.

\section{References}

Agrawal AA. 2007 Macroevolution of plant defense strategies. Trends Ecol. Evol. 22, 103 - 109. (doi: 10.1016/j.tree.2006.10.012)

Alcántara JM, Rey P J. 2003 Conflicting selection pressures on seed size: evolutionary ecology of fruit size in a bird-dispersed tree, Olea europaea. J. Evol. Biol. 16, 1168 - 1176. (doi: 10.1046/j.1420-9101.2003.00618.x)

Alencar LRV, Martins M, Burin G, Quental TB. 2017 Arboreality constrains morphological evolution but not species diversification in vipers. Proc. R. Soc. 284, 20171775. (doi: 10.1098/rspb.2017.1775) 
Arnold SJ. 1992 Constraints on phenotypic evolution. Am. Nat. 140, S85 - S107. (doi: $10.1086 / 285398)$

Baudouin L, Lebrun P. 2009 Coconut (Cocos nucifera L.) DNA studies support the hypothesis of an ancient Austronesian migration from Southeast Asia to America. Gen. Res. C. Evol. 56, 257-262. (doi: 10.1007/s10722-008-9362-6)

Beaulieu JM, O'Meara B. 2016 OUwie: Analysis of evolutionary rates in an OU framework. R package version 1.50 .

(https://CRAN.R-project.org/package=OUwie)

Beck H. 2006 A review of peccary-palm interactions and their ecological ramifications across the Neotropics. J. Mam. 87, 519-530. (doi: 10.1644/05-MAMM-A-174R1.1)

Bell AD. 1997 Plant form: an illustrated guide to flowering plant morphology. Oxford University Press, Oxford, U.K

Belovsky GE, Schmitz OJ, Slade JB, Dawson TJ. 1991 Effects of spines and thorns on Australian arid zone herbivores of different body masses. Oecologia 88, 521-528. (doi:10.1007/BF00317715)

Berry EJ, Gorchov DL, Endress BA, Stevens MHH. 2008 Source-sink dynamics within a plant population: The impact of substrate and herbivory on palm demography. Pop. Ecol. 50, 63-77. (doi: 10.1007/s10144-007-0067-z)

Bodmer RE. 1991 Strategies of seed dispersal and seed predation in Amazonian ungulates. Biotropica 23, 255 - 261. (doi.org/10.2307/2388202)

Brodie JF. 2017 Evolutionary cascades induced by large frugivores. Proc. Natl Acad. Sci. USA 114, 11998-12002. (doi: 10.1073/pnas.1710172114) 
Burin G, Kissling WD, Guimarães Jr PR, Şekercioğlu ÇH, Quental TB. 2016 Omnivory in birds is a macroevolutionary sink. Nature Comm. 7, 11250 (doi: 10.1038/ncomms 11250 )

Burnham KP, Anderson DR, editors. 2004 Model selection and multimodel inference. Springer New York. (doi:10.1007/b97636)

Burns KC, Cazetta E, Galetti M, Valido A, Schaefer HM. 2009 Geographic patterns in fruit colour diversity: Do leaves constrain the colour of fleshy fruits? Oecologia 159, 337-343. (doi:10.1007/s00442-008-1227-3)

Cazetta E, Schaefer HM, Galetti M. 2009 Why are fruits colorful? the relative importance of achromatic and chromatic contrasts for detection by birds. Evol. Ecol. 23, 233-244. (doi:10.1007/s10682-007-9217-1)

Chapman LJ, Chapman CA, Wrangham RW. 1992 Balanites wilsoniana: elephant dependent dispersal?J. Trop. Ecol. (doi:10.1017/s0266467400006519)

Charles-Dominique T, Davies TJ, Hempson GP, Bezeng BS, Daru BH, Kabongo RM, Maurin O, Muasya AM, Bank M, Bond WJ. 2016 Spiny plants, mammal browsers, and the origin of African savannas. Proc. Natl Acad. Sci. USA 113, E5572-E5579. (doi: 10.1073/pnas.1607493113)

Connell JH. 1971 On the role of natural enemies in preventing competitive exclusion in some marine animals and in rain forest trees. Dyn. pop. 298, 312.

Cooper SM, Owen-smith N. 1986 Effects of plant spinescence on large mammalian herbivores. Oecologia 68, 446-455. (doi:10.1007/BF01036753) 
Cornwell W, Nakagawa S. 2017 Phylogenetic comparative methods. Curr. Biol. 27, R333-R336. (doi: 10.1016/j.cub.2017.03.049)

Couvreur T, Baker W. 2013 Tropical rain forest evolution: palms as a model group. BMC Biol. 11, 48. (doi: 10.1186/1741-7007-11-48)

Dracxler CM, Forget PM. 2017 Seed caching by rodents favours seedling establishment of two palm species in a lowland Atlantic forest remnant. J. Trop. Ecol. 33, 228-231. (doi:10.1017/S0266467417000128)

Eriksson O. 2016 Evolution of angiosperm seed disperser mutualisms : the timing of origins and their consequences for coevolutionary interactions between angiosperms and frugivores. Biol. Rev. 91, 168-186. (doi:10.1111/brv.12164)

Evert RF, Eichhorn SE. 2013 Raven: biology of plants, 8nd. edition. No.581

Faurby S, Eiserhardt WL, Baker WJ, Svenning JC. 2016 An all-evidence species-level supertree for the palms (Arecaceae). Mol. Phyl. Evol. 100, 57-69. (doi:10.1016/j.ympev.2016.03.002)

Felsenstein J. 1985 Phylogenies and the Comparative Method. Am. Nat. 125, 1-15. (doi:10.1086/284325)

Forest F, Chase MW, Persson C, Crane PR, Hawkins JA. 2007 The role of biotic and abiotic factors in evolution of ant dispersal in the milkwort family (Polygalaceae). Evolution 61, 1675-1694. (doi:10.1111/j.1558-5646.2007.00138.x)

Fleming TH, Kress WJ. 2013 The ornaments of life: coevolution and conservation in the tropics. Chicago, IL: University of Chicago Press. (doi: 10.7208/chicago/9780226023328.001.0001) 
Freckleton RP, Harvey PH, Pagel M. 2002 Phylogenetic Analysis and Comparative Data: A Test and Review of Evidence. Am. Nat. 160, 712-726. (doi:10.1086/343873)

Futuyma DJ. 2010 Evolutionary constraint and ecological consequences. Evolution 64, 1865-1884. (doi:10.1111/j.1558-5646.2010.00960.x)

Fuzessy LF, Janson C, Silveira FA. 2018 Effects of seed size and frugivory degree on dispersal by Neotropical frugivores. Acta Oecol. 93, 41-47. (doi:10.1016/j.actao.2018.10.004)

Galetti M, Donatti CI, Pires AS, Guimarães PR, Jordano P. 2006 Seed survival and dispersal of an endemic Atlantic forest palm: The combined effects of defaunation and forest fragmentation. Bot. J. Linn. Soc. 151, 141-149. (doi:10.1111/j.1095-8339.2006.00529.x)

Galetti M, Donatti CI, Pizo MA, Giacomini HC. 2008 Big Fish are the Best: Seed Dispersal of Bactris glaucescens by the Pacu Fish (Piaractus mesopotamicus) in the Pantanal, Brazil. Biotropica 40, 386-389. (doi:10.1111/j.1744-7429.2007.00378.x)

Galetti M et al. 2013 Functional extinction of birds drives rapid evolutionary changes in seed size. Science 340, 1086-1090. (doi:10.1126/science.1233774)

Gautier-Hion A et al. 1985 Fruit characters as a basis of fruit choice and seed dispersal in a tropical forest vertebrate community. Oecologia 65, 324-337. (doi:10.1007/bf00378906)

Goheen JR, Young TP, Keesing F, Palmer TM. 2007 Consequences of herbivory by native ungulates for the reproduction of a savanna tree. J. Ecol. 95, 129-138. (doi: $10.1111 / \mathrm{j} .1365-2745.2006 .01196 . x)$ 
Göldel B, Araujo AC, Kissling WD, Svenning JC. 2016 Impacts of large herbivores on spinescence and abundance of palms in the Pantanal, Brazil. Bot. J. Linn. Soc. 182, 465-479. (doi:10.1111/boj.12420)

Gómez JM. 2004 Bigger is not always better: conflicting selective pressures on seed size in Quercus ilex. Evolution 58, 71-80. (doi:10.1554/02-617)

Gómez JM, Verdú M. 2012 Mutualism with plants drives primate diversification. Syst. Biol. 61, 567-577. (doi:10.1093/sysbio/syr127)

Govaerts R, Dransfield J, Zona SF, Hode DR, Henderson A, 2011. World Checklist of Arecaceae. Richmond, UK: facilitated by the Royal Botanic Gardens, Kew. See http://apps.kew.org/wcsp/. Retrieved November 2013

Grubb PJ. 1992 A positive distrust in simplicity - Lessons from plant defences and from competition among plants and among animals. J. Ecol. 80, 585-610. (doi:10.2307/2260852)

Guimarães PR, Galetti M, Jordano P. 2008 Seed dispersal anachronisms: Rethinking the fruits extinct megafauna ate. PLoS ONE 3, e1745. (doi:10.1371/journal.pone.0001745)

Hansen TF. 1997 Stabilizing selection and the comparative analysis of adaptation. Evolution 51, 1341-1351. (doi:10.2307/2411186)

Harmon LJ, Weir JT, Brock CD, Glor RE, Challenger W. 2007 GEIGER: investigating evolutionary radiations. Bioinformatics 24, 129-131. (doi:10.1093/bioinformatics/btm538)

Henderson A, Galeano-Garces G, Bernal R. 1997 Field guide to the palms of the Americas. Princeton, NJ: Princeton University Press. 
Jackson MB (ed.). 1986 New Root Formation in Plants and Cuttings. Series Developments in plant and soil sciences $\mathrm{n}^{\circ}$ 20. Martinus Nijhoff Publishers, a member of the Kluwer Academic Publishers Group. Da ordrecht / Boston / Lancaster. p.80-81

Janson CH. 1983 Adaptation of fruit morphology to dispersal agents in a neotropical Forest. Science 219, 187-189. (doi:10.1126/science.219.4581.187)

Janzen DH. 1970 Herbivores and the number of tree species in tropical forests. Am. Nat. 104, 501-528. (doi:10.1086/282687)

Janzen DH, Martin PS. 1982 Neotropical anachronisms: The fruits the gomphotheres ate. Science 215, 19-27. (doi:10.1126/science.215.4528.19)

Janzen DH. 1986 Chihuahuan desert nopaleras: defaunated big mammal vegetation. Ann. Rev. Ecol. Syst. 17, 595-636. (doi: 10.1146/annurev.es.17.110186.003115)

Jordano P. 1995a Angiosperm fleshy fruits and seed dispersers: A comparative analysis of adaptation and constraints in plant-animal interactions. Am. Nat. 145, 163-191. (doi:10.1086/285735)

Jordano P. 1995b Frugivore-mediated selection on fruit and seed size : Birds and St. Lucie's Cherry, Prunus Mahaleb. Ecology 76, 2627-2639. (doi: $10.2307 / 2265833)$

Jordano P. 2000 Fruits and frugivory. In Seeds: the ecology of regeneration in plant communities 2 (ed. M Fenner), pp. 125-166. Wallingford, UK: CABI Publishing.

Jordano P. 2017 What is long-distance dispersal? And a taxonomy of dispersal events. J. Ecol. 105, 75-84. (doi:10.1111/1365-2745.12690) 
Kissling WD et al. 2012 Quaternary and pre-Quaternary historical legacies in the global distribution of a major tropical plant lineage. Glob. Ecol. Biogeogr. 21, 909-921. (doi:10.1111/j.1466-8238.2011.00728.x)

Liesenfeld MVA, Vieira G. 2018 Postfire palm resprouting in the Amazonian Forest: are underground stems an advantage? Persp. Rur. 16, 11-23. (doi:10.15359/prne.16-31.1)

Lomáscolo SB, Speranza P, Kimball RT. 2008 Correlated evolution of fig size and color supports the dispersal syndromes hypothesis. Oecologia 156, 783-796. (doi:10.1007/s00442-008-1023-0)

Lomáscolo SB, Schaefer HM. 2010a Signal convergence in fruits: A result of selection by frugivores? J. Evol. Biol. 23, 614-624. (doi:10.1111/j.1420-9101.2010.01931.x)

Lomáscolo SB, Levey DJ, Kimball RT, Bolker BM, Alborn HT. 2010b Dispersers shape fruit diversity in Ficus (Moraceae). Proc. Natl Acad. Sci. USA 107, 14668-14672. (doi:10.1073/pnas.1008773107)

Lord JM. 2004 Frugivore gape size and the evolution of fruit size and shape in southern hemisphere floras. Austral Ecol. 29, 430-436. (doi: 10.1111/j.1442-9993.2004.01382.x)

Lorenzi H, Souza HD, Costa JDM, Cerqueira LD, Ferreira E. 2004 Palmeiras brasileiras e exóticas cultivadas. Nova Odessa, SP: Instituto Plantarum

Milewski AV, Young TP, Madden D. 1991 Thorns as induced defenses: experimental Evidence. Oecologia 86, 70-75. (doi: 10.1007/BF00317391) 
Muñoz G, Trøjelsgaard K, Kissling WD. 2019 A synthesis of animal-mediated seed dispersal of palms reveals distinct biogeographical differences in species interactions. J. Biog. 46, 466-484. (doi: 10.1111/jbi.13493)

Nevo O, Valenta K, Tevlin AG, Omeja P, Styler SA, Jackson DJ, Chapman CA, Ayasse M. 2017 Fruit defence syndromes: the independent evolution of mechanical and chemical defences. Evolutionary Ecology 31, 913-923. (doi:10.1007/s10682-017-9919-y)

Nevo O, Valenta K, Razafimandimby D, Melin AD, Ayasse M, Chapman CA. 2018a Frugivores and the evolution of fruit colour. Biol. Lett. 14, 20180377. (doi:10.1080/0194262X.2014.909757)

Nevo O, Razafimandimby D, Antonio J, Jeffrey J, Schulz S, Ayasse M. 2018b Fruit scent as an evolved signal to primate seed dispersal. Science Adv. 4, 1-8. (doi: 10.1126/sciadv.aat4871)

Onstein RE, Linder HP. 2016 Beyond climate: Convergence in fast evolving sclerophylls in Cape and Australian Rhamnaceae predates the mediterranean climate. J. Ecol. 104, 665-677. (doi:10.1111/1365-2745.12538)

Onstein RE, Baker WJ, Couvreur TLP, Faurby S, Svenning JC, Kissling WD. 2017 Frugivory-related traits promote speciation of tropical palms. Nature Ecol. Evol 1, 1903-1911. (doi:10.1038/s41559-017-0348-7)

Onstein RE, Baker WJ, Couvreur TLP, Faurby S, Herrera-Alsina L, Svenning JC, Kissling WD. 2018 To adapt or go extinct? The fate of megafaunal palm fruits under past global change. Proc. R. Soc. B 285. 20180882 (doi:10.1098/rspb.2018.0882) 
Orrock JL, Levey DJ, Danielson BJ, Damschen EI. 2006 Seed predation, not seed dispersal, explains the landscape-level abundance of an early-successional plant. J. Ecol. 94, 838-845. (doi:10.1111/j.1365-2745.2006.01125.x)

Owen-Smith RN. 1992 Megaherbivores: the influence of very large body size on ecology. Cambridge university press.

Palmer RR, Koprowski JL. 2014 Feeding behavior and activity patterns of Amazon red squirrels. Mammalia, 78, 303-313. (doi:10.1515/mammalia-2013-0083)

Parolin P. 2000 Seed mass in Amazonian floodplain forests with contrasting nutrient supplies. J. Trop. Ecol. 16, 417-428. (doi: 10.1017/S0266467400001486)

Pires MM, Guimarães PR, Galetti M, Jordano P. 2018 Pleistocene megafaunal extinctions and the functional loss of long-distance seed-dispersal services. Ecography 41, 153-163. (doi: 10.1111/ecog.03163)

Revell LJ. 2012 phytools : an R package for phylogenetic comparative biology (and other things). Meth. Ecol. Evol. 3, 217-223. (doi:10.1111/j.2041-210X.2011.00169.x)

Rodgerson L. 1998 Mechanical defense in seeds adapted for ant dispersal. Ecology 79, 1669-1677. (doi:10.1890/0012-9658(1998)079\%5B1669:MDISAF\%5D2.0.CO;2)

Sallabanks R. 1993 Hierarchical mechanisms of fruit selection by an avian frugivore. Ecology 74, 1326-1336. (doi: 10.2307/1940063)

Schmidt V, Schaefer HM, Winkler H. 2004 Conspicuousness, not colour as foraging cue in plant-animal interactions. Oikos 106, 551-557. (doi: 10.1111/j.0030-1299.2004.12769.x) 
Schupp EW, Jordano P, Gómez JM. 2010 Seed dispersal effectiveness revisited: a conceptual review. New Phytologist 188, 333-353. (doi:10.1111/j.1469-8137.2010.03402.x)

Sekar N, Sukumar R. 2015 The Asian elephant is amongst the top three frugivores of two tree species with easily edible fruit J. Trop. Ecol. 31, 385-394. (doi:10.1017/S0266467415000346)

Serrano-Serrano ML, Perret M, Guignard M, Chautems A, Silvestro D, Salamin N. 2015. Decoupled evolution of floral traits and climatic preferences in a clade of Neotropical Gesneriaceae. BMC Evol. Biol. 15, 1-12. (doi: $10.1186 / \mathrm{s} 12862-015-0527-6)$

Silvius KM. 2005 Seed fate: predation, dispersal, and seedling establishment. pp. 45-54. CABI.

Simpson MG. 2010 "Plant Morphology". In: Plant Systematics, 2nd. edition. Elsevier Academic Press. Chapter 9.

Smythe N. 1989 Seed Survival in the Palm Astrocaryum standleyanum : Evidence for dependence upon its seed dispersers. Biotropica 21, 50-56. (doi: $10.2307 / 2388441)$

Staggemeier VG, Cazetta E, Morellato LPC. 2016 Hyperdominance in fruit production in the Brazilian Atlantic rain forest: the functional role of plants in sustaining frugivores. Biotropica 49, 71-82. (doi:10.1111/btp.12358)

Steege H et. al. 2013 Hyperdominance in the Amazonian Tree Flora. Science 342, 1243092-1243092. (doi:10.1126/science.1243092) 
Strauss SY, Agrawal AA. 1999 The ecology and evolution of plant tolerance to herbivory. Trends Ecol. Evol. 14, 179-185. (doi:10.1016/S0169-5347(98)01576-6)

Strauss SY, Irwin RE. 2004 Ecological and evolutionary consequences of multispecies plant-animal interactions. Ann. Review Ecol. Syst. 35, 435-466. (doi:10.1146/annurev.ecolsys.35.112202.130215)

Thompson JN. 2013 Relentless evolution. University of Chicago Press.

Tomlinson PB. 1990 The structural biology of palms. Oxford University Press.

Valenta K, Kalbitzer U, Razafimandimby D, Omeja P, Ayasse M, Chapman CA, Nevo O. 2018 The evolution of fruit colour: phylogeny, abiotic factors and the role of mutualists. Scientific Rep. 8, 1-8. (doi:10.1038/s41598-018-32604-x)

Vander Wall SB, Beck MJ. 2011 A Comparison of Frugivory and Scatter-Hoarding Seed-Dispersal Syndromes. The Botanical Review 78, 10-31. (doi:10.1007/s12229-011-9093-9)

Voigt FA, Bleher B, Fietz J, Ganzhorn JU, Schwa D, Böhning-Gaese K. 2004 A comparison of morphological and chemical fruit traits between two sites with different frugivore assemblages. Oecologia 141, 94-104. (doi:10.1007/s00442-004-1654-8)

Voje KL, Holen OH, Liow LH, Stenseth NC. 2015 The role of biotic forces in driving macroevolution: beyond the Red Queen. Proc. $R$. Soc. $B$ 282, 20150186-20150186. (doi:10.1098/rspb.2015.0186)

Zona S, Henderson A. 1989 A review of animal-mediated seed dispersal of palms. Selbyana 11, 6-21. 
Wenny DG. 2001 Advantages of seed dispersal: A re-evaluation of directed dispersal. Evol. Ecol. Res. 3, 51-74.

Willson MF, Whelan CJ. 1990 The evolution of fruit color in fleshy-fruited plants. Am. Nat. 136, 790-809. (doi:10.1086/285132)

\section{Supplementary material}

\section{Exploratory Analysis}

We characterized the distribution of each trait and examined if the distributions of fruit length differed between palms with colorful and dull-colored fruits or between palms with and without spines by performing a two sample unequal variance (Welch's) t-test. A simple statistical test of the difference in fruit size between plants with colorful (mean = $3.30 \mathrm{~cm})$ and dull-colored fruits $($ mean $=1.36 \mathrm{~cm})$ suggests that dull-colored fruits are generally larger than colorful ones $(t=-12.07, p<0.0001)$ (figure 1$)$. However there was no difference in mean fruit size between palms with spines $($ mean $=2.32 \mathrm{~cm}$ ) and palms without spines $($ mean $=2.38 \mathrm{~cm})(t=0.38 ; p=0.70)$ (figure 1$)$ when the phylogenetic component is not taken into account.

\section{Evolutionary regime of fruit length}

For fruit length, we used the "fitContinuous" function from "geiger" R package and compared the fit of Brownian-Motion (BM), Ornstein-Uhlenbeck (OU) and Early-burst (EB) models. The BM model assumes trait evolution occurs through a random walk governed by the evolutionary rate parameter $\left(\sigma^{2}\right)$. The OU model assumes a constrained 
random walk where trait values change towards an optimum $(\theta)$ with strength selection $(a)$ (Hansen 1997). The EB model assumes the rate of evolution of trait, $\rho$, changes over time, increasing or decreasing exponentially with rate $r$.

Our tests using trait evolution models suggest that the OU model, with mean optimum fruit size of $\theta=2.24 \mathrm{~cm}$ (mean $\alpha=0.43$, mean $\left.\sigma^{2}=3.95\right)$, has the best fit for fruit length across all 100 phylogenies.

\section{Evolutionary relationship between fruit size, colors and spines}

Here we present the rates of evolution and evolutionary optima estimated by OUwie analyses (Figure S.1 - 2). Additionally, we present the results of analyses without genus Attalea ( Figura S.3 - 4).

We successfully fitted the models that allows different $\alpha$ for each evolutionary scenario (OUMVA and OUMA) in only $20 \%$ of the fitted reconstructions. $80 \%$ of the fitted OUMVA and OUMA generated negative eigenvalues of the Hessian matrix and/or returned very unrealistic fruit size optima. This problem with OUMVA and OUMA in OUwie function was registered in another works (e.g., Alencar et al. 2017). So, because we are interested mainly in the evolutionary optima $(\theta)$, here we excluded the OUMA and OUMVA of the selection model analysis. The results with OUMA and OUMVA are presented in figure S5 - 9 and yielded qualitatively identical results to presented below.
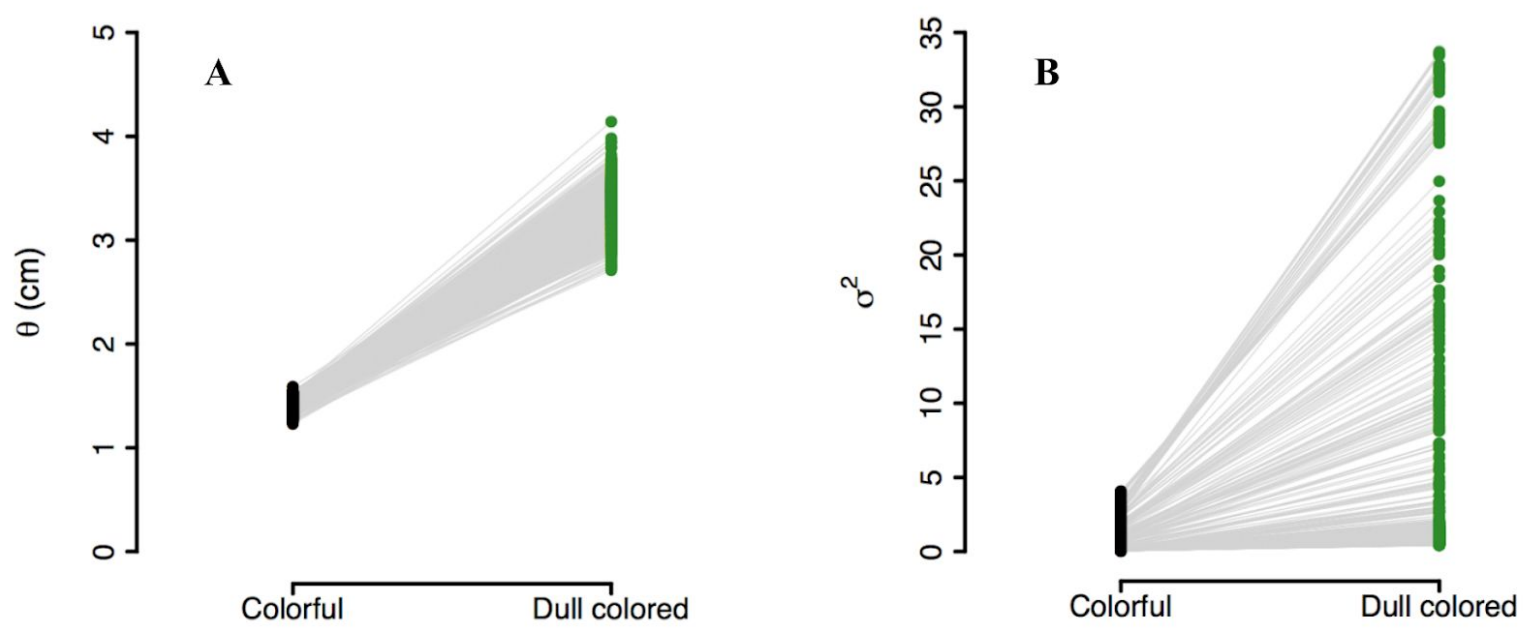
Figure S.1: (A) Fruit size evolutionary optima $(\theta)$ and $(\mathrm{B})$ evolutionary rate parâmter $\left(\sigma^{2}\right)$ estimated for the OUMV in lineages with colorful fruits and lineages with dull colored fruits. Each line represents one fitted reconstruction.
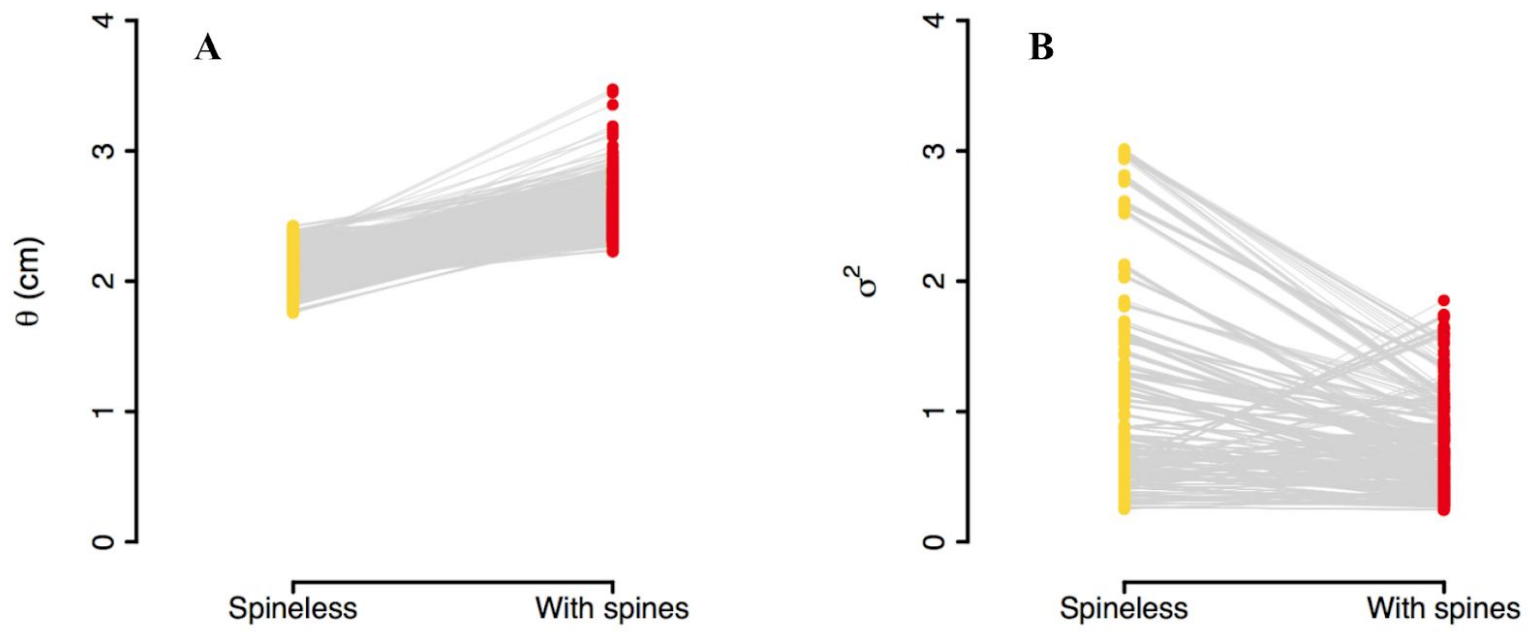

Figure S.2: (A) Fruit size evolutionary optima $(\theta)$ and $(\mathrm{B})$ evolutionary rate parâmeter $\left(\sigma^{2}\right)$ estimated for the OUMV in lineages spineless and with spines. Each line represents one fitted reconstruction.
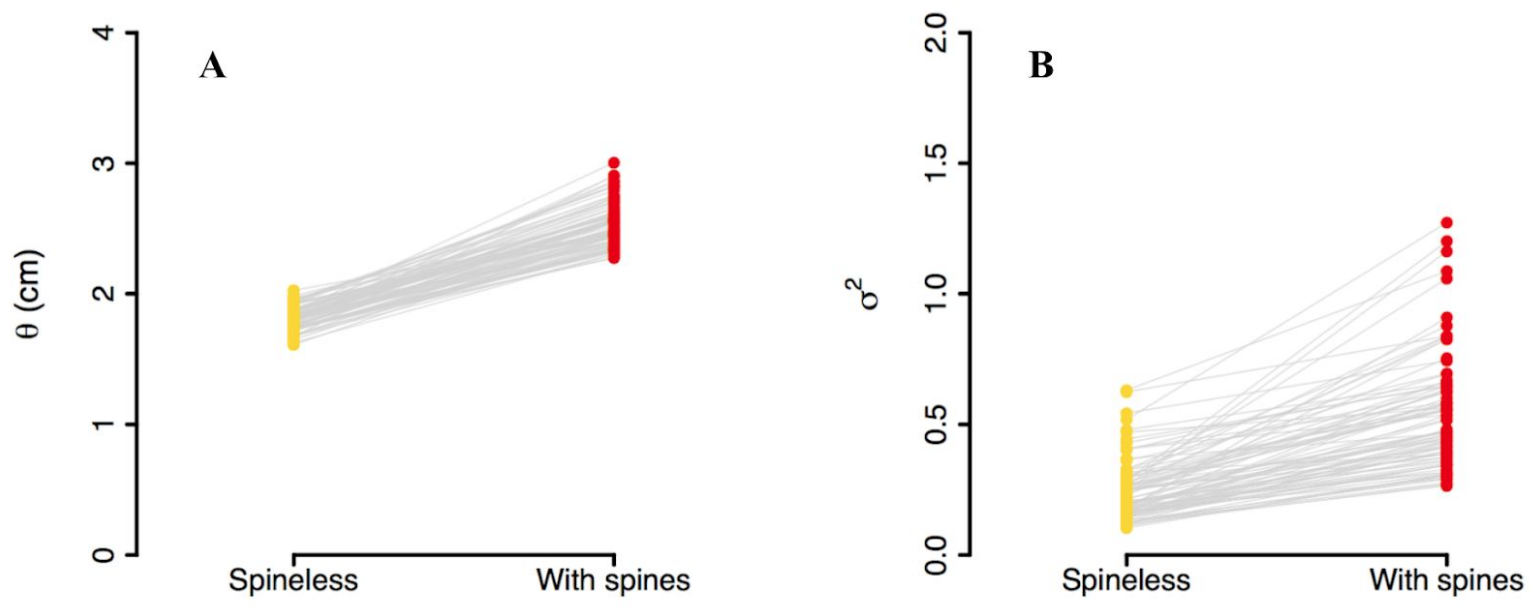
Figure S.3: (A) Fruit size evolutionary optima $(\theta)$ and (B) evolutionary rate parâmter $\left(\sigma^{2}\right)$ estimated for the OUMV in lineages spineless and with spines without considering genus Attalea. Each line represents one fitted reconstruction.

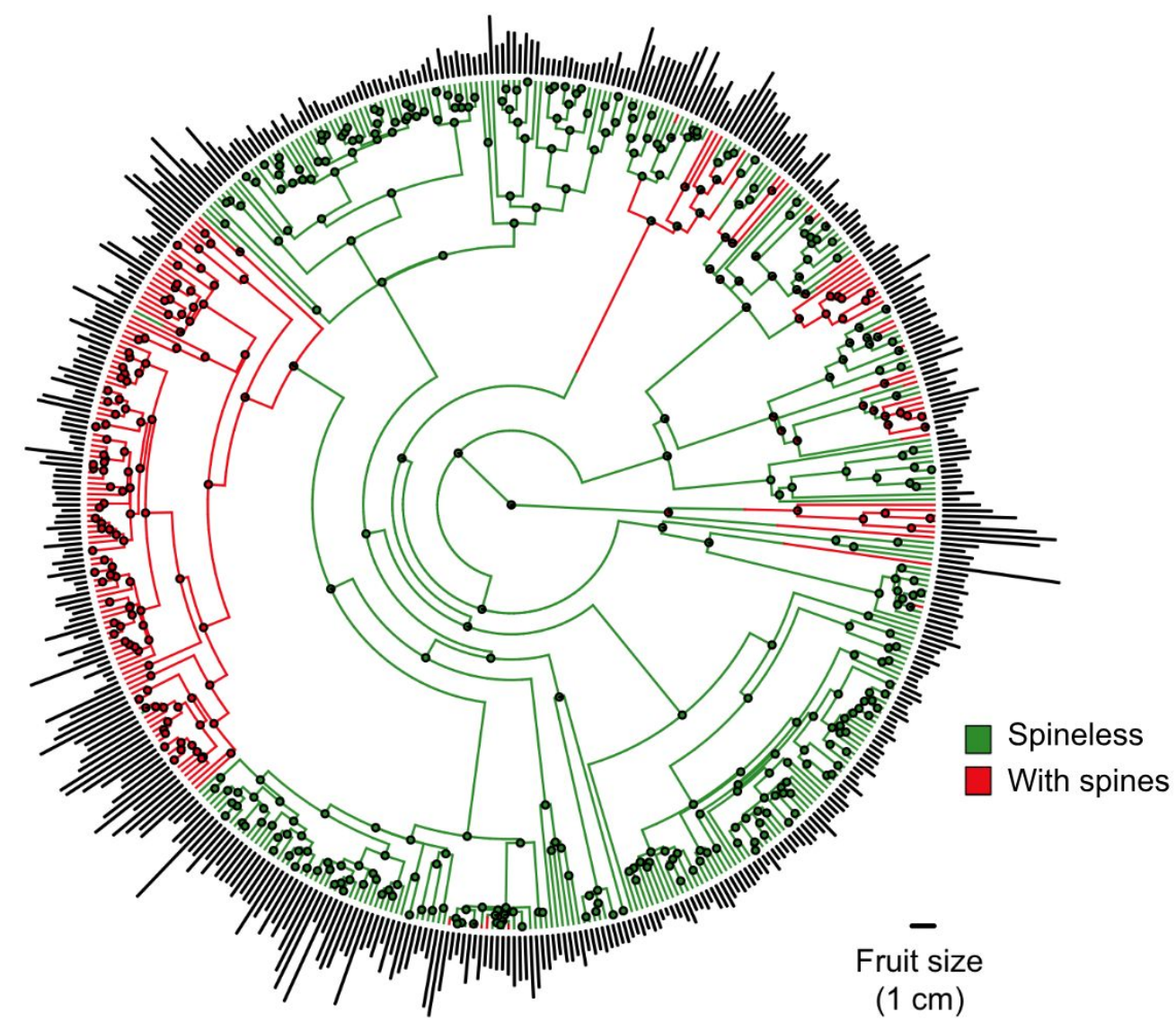

Figure S.4: Reconstruction of ancestral states for spines in Neotropical palms without the genus Attalea. Red branches indicate the presence of spines in a given lineage and green branches indicate the absence of spines. Bars in the tips indicate the fruit length. The circles indicate the distribution for estimates of the marginal ancestral states. 


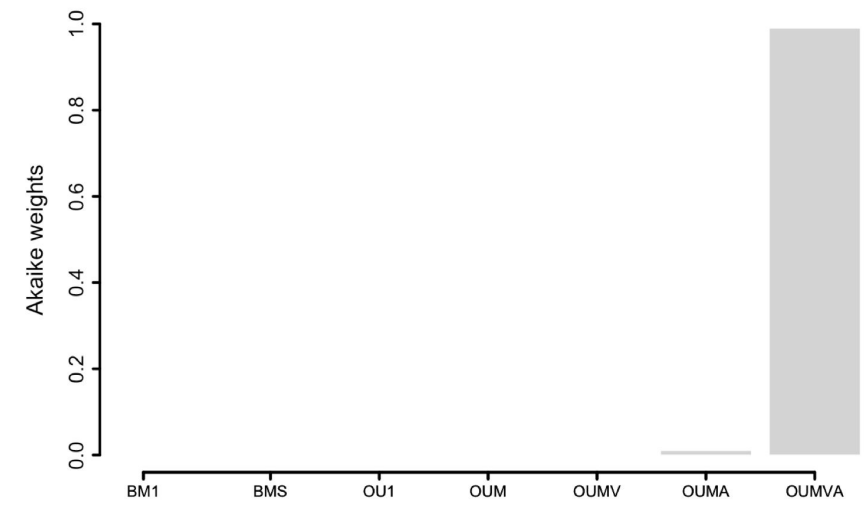

Figure S.5: Akaike weights of the evolutionary models estimated for fruit length in lineages with colorful fruits and dull-colored fruits.
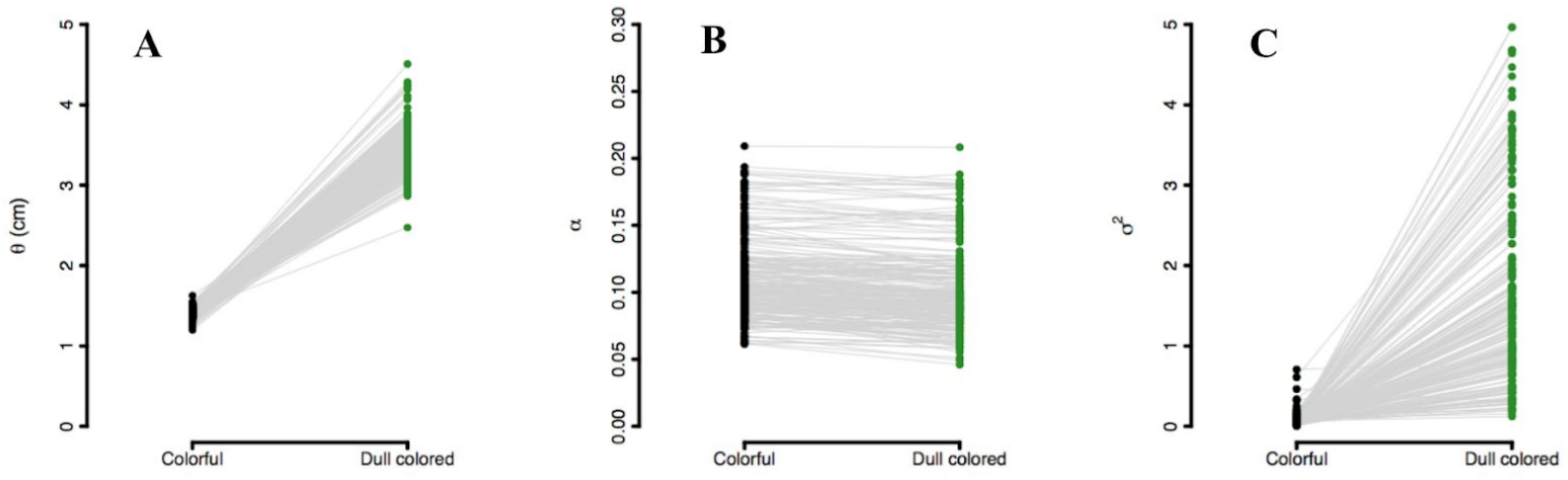

Figure S.6: Model parameters estimated for the OUMVA. Each line represents one fitted reconstruction. 


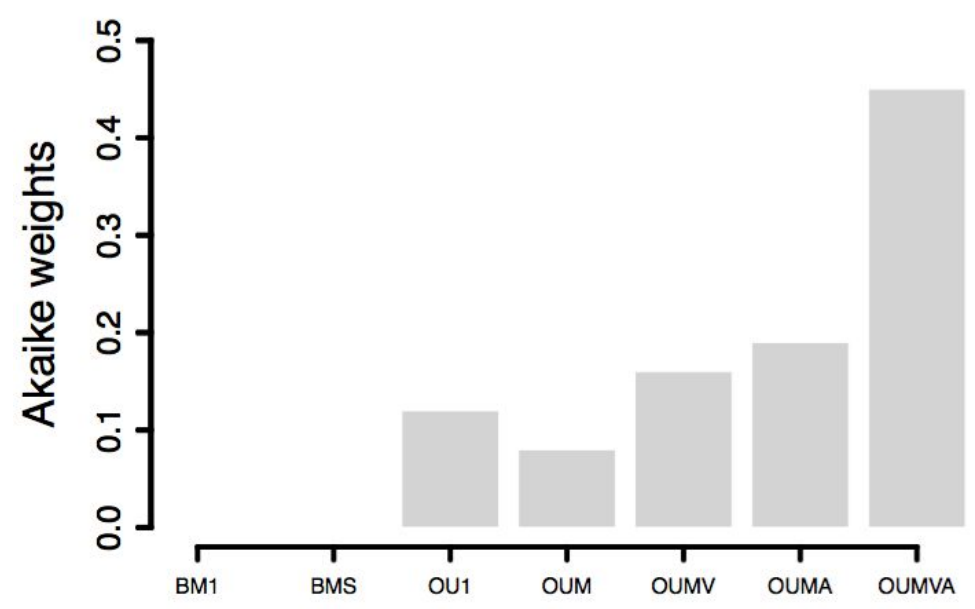

Figure S.7: Akaike weights of the evolutionary models estimated for fruit length in lineages with spines and without spines.
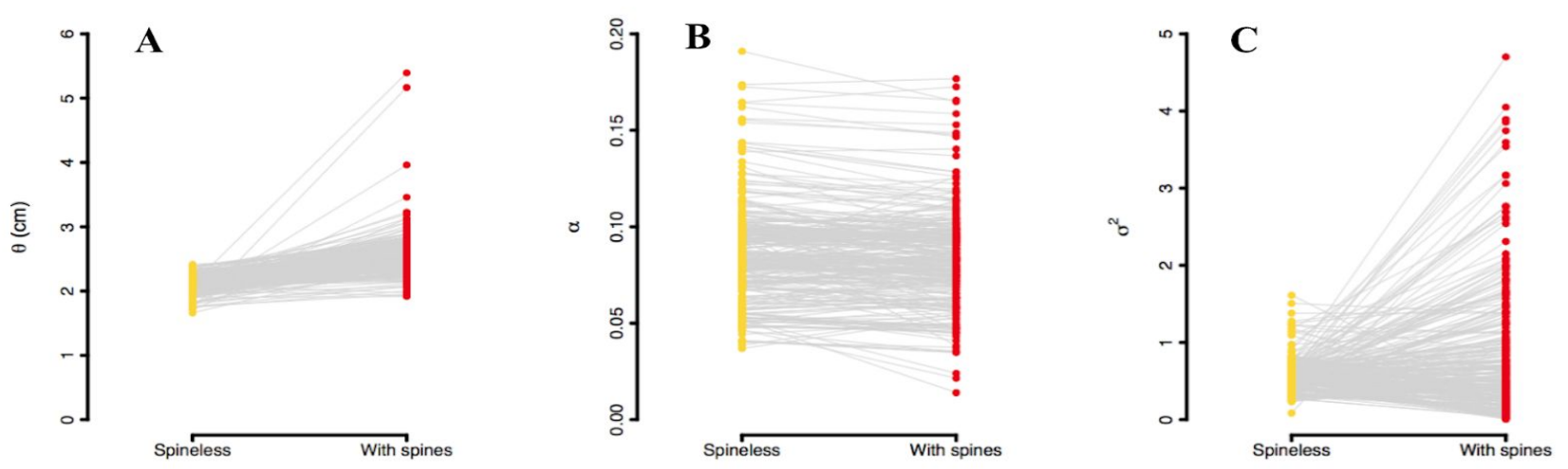

Figure S.8: Model parameters estimated for the OUMVA. Each line represents one fitted reconstruction. 

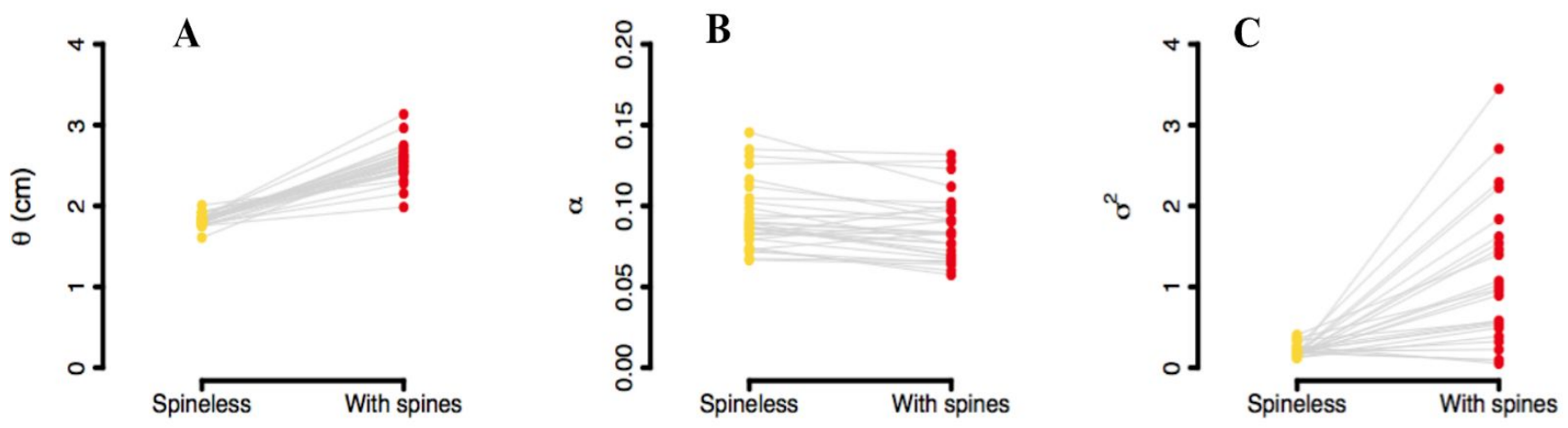

Figure S.9: Model parameters estimated for the OUMVA without the genus Attalea. Each line represents one fitted reconstruction.

Table S1: AICc of transition rates models (ER and ARD) for fruit color.

https://docs.google.com/spreadsheets/d/1 CEg-V-GCNVdCOkEDVek8M iRGDeg1Z3CM gnovXAMFw/edit?usp=sharing

Table S2: AICc of transition rates models (ER and ARD) for absence/presence of spines.

https://docs.google.com/spreadsheets/d/1D 1ht-T_S zsWwFuepfu8P4WNyDz qQdWAe7q $\underline{\text { bVGZbQ/edit?usp=sharing }}$

Table S3: Transition rates between colorful fruits and dull-colored fruits and vice-versa.

https://docs.google.com/spreadsheets/d/1vqsg4HYg7vnZUAbMGE9OJf9d78yvr6DgVGWn $\underline{8 z z Q} 4 b Q / e d i t ? u s p=$ sharing

Table S4: Transition rates between with spines and spineless and vice-versa.

https://docs.google.com/spreadsheets/d/13K0wH5WPp0jMVJBEZwxc3xAgPUiHlB1U0mF $\underline{\text { nOyT0yss/edit?usp }=\text { sharing }}$ 
